\title{
A Critical Assessment of UH-60 Main Rotor Blade Airfoil Data
}

Joseph Totah

September 1993

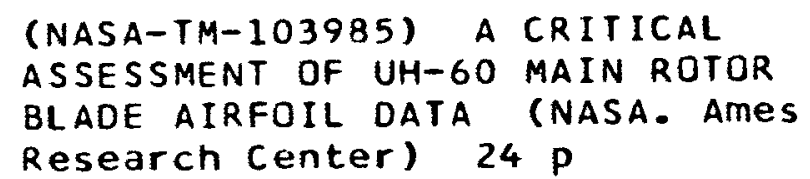

(NASA-TM-103985) A CRITICAL
ASSESSMENT OF UH-60 MAIN ROTOR BLADE AIRFOIL DATA (NASA. Ames
Research Center) $24 \mathrm{P}$

N94-32063

Unclas

$63 / 02$

0005471 
NASA Technical Memorandum 103985

\section{A Critical Assessment of UH-60 Main Rotor Blade Airfoil Data}

Joseph Totah, Ames Research Center, Moffett Field, California

September 1993

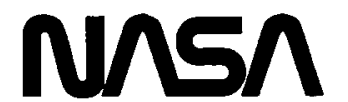

National Aeronautics and

Space Administration 
Summary

Many current comprchensive rotorcraft analyses employ lifting-line methods that requirc main rotor blade airfoil data, typically obtained from wind tunnel tests. In order to effectively evaluate these lifting-line methods, it is of the utmost importance to ensure that the airfoil section data are frec of inaccuracics. A critical assessment of the SC1095 and SC1094R8 airfoil data uscd on the UH-60 main rotor blade was performed for that reason. Ninc sources of wind tunnel data were examined, all of which contain SC1095 data and four of which also contain SC1094R8 data. Findings indicate that the most accurate data were generated in 1982 at the 11-Foot Wind Tunnel Facility at NASA Amcs Rescarch Center and in 1985 at the 6-inch-by-22-inch transonic wind tunncl facility at Ohio State University. It has not been determined if data from these two sources are sufficiently accurate for their use in comprehensive rotorcraft analytical models of the UH-60. It is recommended that new airfoil tables be created for both airfoils using the cxisting data. Additional wind tunnel experimentation is also recommended to provide high quality data for correlation with these new airfoil tables.

\section{Symbols}

a

b

c

$\mathrm{C}_{\mathrm{d}}$

$\mathrm{C}_{\mathrm{d}_{\mathrm{o}}}$

$c_{\text {f }}$

$\mathrm{C}_{l}$

$\mathrm{C}_{\text {max }}$

$\mathrm{C}_{\alpha}$

$\mathrm{C}_{\alpha_{\max }}$

$\mathrm{C}_{\alpha_{\min }}$

$\mathrm{C}_{\alpha_{\text {recovered }}}$

$\mathrm{C}_{\mathrm{S}} / \mathrm{cF}_{\mathrm{F}}$

h
K

$\mathrm{L}_{\mathrm{p}} / \mathrm{c}$

(L/D) $\max$

L

M

$\mathbf{M}_{1}$

MDD

$P_{\text {error }}$

Pl

$P_{u}$

$t / c$

$\mathrm{S}_{\mathrm{A}}$

$R_{c}$

$\mathrm{R}_{\mathrm{N}_{\mathrm{O}}}$

V

$\alpha$

$\alpha_{Z L}$

$\beta$

$\mu$

$\partial \mathrm{C}_{\boldsymbol{\alpha}^{\prime}} / \partial \mathrm{M}$

$\partial \mathrm{C}_{\mathrm{d}_{\mathrm{o}}} / \partial \mathrm{M}$

$\gamma$

$\rho$ correlation parameter for airfoil section drag due to lift

airfoil perimeter/chord

maximum lift-to-drag ratio

lift, lb

Mach number

Mach number at which the slope of $\mathrm{C}_{l_{\alpha}}$ changes from "+" to "-,"

drag divergence Mach number

measured pressurc transduccr stcady

bias error, psia

lower surface pressure, psia

upper surface pressure, psia

thickncss-to-chord ratio

mean valuc of airfoil pressurc cocfficicnt

free-stream Reynolds number

Reynolds number in drag correlation

free-stream velocity, $\mathrm{ft} / \mathrm{s}$

angle of attack, deg or rad

zcro-lift anglc of attack, dcg or rad

$\sqrt{1-M^{2}}$

$1 / \beta$

$\mathrm{C}_{l_{\alpha}}$ gradient at speeds greater than $\mathrm{M}_{1}$

$C_{d_{o}}$ gradient at speeds greater than MDD

ratio of spccific hcats, 1.4 for air

density, slugs $/ \mathrm{ft}^{3}$

\section{Introduction}

NASA, in coopcration with the U.S. Army Aviation and Troop Command (ATCOM), is cngaged in a program to provide and validate the tcchnology and methodology required to improve the performance, dynamics, acoustics, handling qualities, and cost of civil and military rotorcraft. A major element of this program, the UH-60 Phase II Airloads Program, consists of ground based and flight rescarch of the UH-60 Blackhawk helicopter with a 
pressure instrumented blade and a full suite of other instrumentation.

NASA and ATCOM arc currently preparing for rigorous analysis mcthodology validation using high quality data generated from the UH-60 Phase II Airloads Program. Analysis methodology validation involves assessing and improving state-of-the-art comprehensive analytical modcls through cxhaustive corrclative studics in performance, dynamics, and rotor structural loads and airloads. In order to assess and improve the theorics and assumptions employed in comprehensive analytical models, accurate vehicle representations must be established.

The main rotor blade airfoil section characteristics arc among the most important parts of the vehiclc reprcsentation. The airfoil sections on the UH-60 Blackhawk helicopter are the SC1095 and SC1094R8 utilized on the main rotor blade shown in figure 1 . The profiles of these airfoils are shown in figure 2 .

Sikorsky Aircraft, a Division of United Tcchnologics Corporation, was taskcd to provide NASA with all known stcady, 2-D wind tunncl data on the SC1095 and SC1094R8 airfoils. Nine data sets (refs. 1-9) were identified and provided to NASA, all of which contained SC1095 data and four of which contained SC1094R8 data. This report documents an assessment of that data for both airfoils.

An cffort similar to the UH-60 Phasc II Airloads Program was performed on an $\mathrm{H}-34$ helicopter by Scheiman in the early 1960s. That experiment has long been a standard for rotor airloads data, but it did not include high speeds. Furthermorc, rotor systems have cvolved dramatically from the carly 1960s. The UH-60 Phasc II Airloads Program will consider high specds and will gather data at much higher sample rates. The U.S. rotorcraft industry has played a key role in defining the requirements for this program to ensure it meets their needs. Also, a formal rccommendation resulting from a pecr revicw of the program in 1990 was a primary motivator for the work presented in this report.

I would like to acknowledge and thank Mr. Robert Flemming from Sikorsky for his thorough review of the data and for his comments, all of which have becn incorporatcd in this report.

\section{Description of Data}

Nine sets of UH-60 airfoil data have been considered. The sources of these data sets which contain SC1095 and SC1094R8 airfoil data are listed in table 1. These data sets are identified in table 1 and throughout this report, as Experiment 1, Experiment 2, and so on, through Experiment 9. Pertinent information about the experiments, the wind tunnel facilitics, airfoils, and mcasurcment devices are also noted in this tablc. Some details of these experiments are discussed in this section.

The primary objectives of three of the experiments were to assess current technology airfoils, either stand-alone or compared with prototypes. Experiments 3 and 8 gathered steady, 2-D data on the SC1095 and SC1094R8 airfoils and compared them to prototype airfoils. Expcriment 7 gathered SC1095 data for correlation with a computational fluid dynamics code.

Evaluation of Experiment 7 data revealed gross discrepancies relative to the data from all the other experiments. The published report documenting this cxperiment noted that inaccurate tunncl wall corrections were applied to generate the reported data (ref. 7). Regrettably, appropriate wall corrections are not available and the tunnel configuration has since been permanently modificd.

Some experiments examincd alternate methods of testing. For example, the primary objective of Expcriment 2 was the testing of a Tunnel Spanning Wing Apparatus (TSW or TSA) which fit inside a wind tunnel test section. The TSW was evaluated in Experiments 2 and 5, and later used in Expcriment 8. Expcriment 2 attributed pre-stall "bumps" in lift cocfficient at high angles of attack to model flexibility. Expcriment 5 gathered data with and without a center span device that alleviated the model flexibility problems noted in Experiment 2. Experiment 5 published two sets of SC1095 wake drag data, identified as 5a and 5b. The 5a drag data accountcd for the differcnce in static pressurcs on cach side of the wakc bchind the airfoil, whercas the $5 b$ drag data did not.

The remaining four experiments were primarily concerned with the study of trends. Experiment 1 considered the influence of various surface irregularities relative to a bascline SC1095 airfoil. Experiment 4 studicd icing conditions rclative to basclinc SC1095 and SC1094R8 airfoil characteristics. This cxpcriment gencrated relatively small amounts of data under normal, non-icing conditions. Data published from two alternate lift 
measurement approaches devised in Experiment 4 were also cvaluated. Experiment 6 studicd the effect of Reynolds number on both the SC1095 and the SC1094R8 airfoils. This experiment documented known problems in determining $\mathrm{C}_{\mathrm{I}_{\max }}$, and the airfoils used in that experiment were tabbed. The tabs were deflected upward approximately 3 degrees. The tabs also changed the thickncss-to-chord ratios to 0.091 and 0.09 for the SC1095 and SC1094R8 airfoils, respectively. Untabbed thickness-to-chord ratios are 0.095 and 0.094 for the SC1095 and SC1094R8, respectively. Finally, Experiment 9 measured the effects of dynamic stall relative to baseline SC1095 steady, 2-D characteristics. Data from Expcriment 9 were limited to specds Icss than $M=0.3$.

In summary, although all of the data from these ninc experiments were cxamincd, Expcriment 7 and some Experiment 4 results were not published in this report. Experiment 7 results were omitted because of the aforementioned problem with the tunnel wall corrections. Expcriment 4 data gathered using the two altcrnatc lift mcasurcment approaches wcre also omitted bccause no attempt was made to address known anomalics noted at certain test conditions. In each instance the experimenter was consulted prior to omitting the results, and concurrence was obtained.

\section{Evaluation Methodology}

The methodology developed by McCroskey (ref. 10) and first applied to NACA 0012 data was used to evaluate the SC1095 and SC1094R8 data. This methodology uses spccific critcria to scparatc accuratc data from inaccuratc data. All the data are then placed into one of four groups that further reflect varying Icvels of accuracy. A short summary of the aforementioned criteria, and the definitions of the four groups are given in this section.

\section{Criteria}

Gencrally spcaking, for $M<0.6$ and between $10^{6}<R_{c}<10^{7}$, accuratc data is distinguished from inaccurate data if they exhibit the following characteristics:

1. 0.10 per degrec $<\beta C_{l_{\alpha}}<2 \pi$ per radian, where $b=\sqrt{1-M^{2}}, 0.10$ is a known boundary, and $2 \pi$ is the theoretical lift-curve slope.

2. $\beta C_{l_{\alpha}}$ and $\beta C_{d_{0}}$ are independent of Mach number.
3. $\beta C_{l_{\alpha}}$ and $\beta C_{d_{o}}$ are slightly dependent on Reynolds number.

\section{Groups}

Four groups were defined by McCroskey to distinguish varying levels of accuracy. A graphical approach is used to place the data into each of these groups. This approach begins with two plots; $\beta C_{l_{\alpha}}$ versus $R_{e}$ and $C_{d_{o}}$ versus $R_{e}$ for data less than $M=0.6$ and between $10^{6}<R_{c}<10^{7}$. Group 1 quality data should have values for both $\beta C_{l_{\alpha}}$ and $C_{d_{0}}$ within \pm 0.0005 and \pm 0.0002 , respectively, of a log curve fit approximation of only the accurate data identified by the aforementioned criteria. Group 1 quality data are of sufficient accuracy for use in comprehensive analytical input models. This is further cxamincd in the Discussion scction.

Group 2 quality data should have values for both $\beta C_{l_{\alpha}}$ and $C_{d_{0}}$ within \pm 0.004 and \pm 0.001 , respectively, of the log curve fit of only the accurate data identified by the aforcmentioned critcria. It has not becn detcrmincd whether Group 2 data arc sufficicntly accuratc for usc in comprchensive analytical modcls. This will also bc examined in the discussion section.

Group 3 quality data should have values for either $\beta C_{l_{\alpha}}$ or $\mathrm{C}_{\mathrm{d}_{\mathrm{o}}}$ within the Group 2 tolerances. Finally, Group 4 quality data have values for both $\beta C_{l_{\alpha}}$ and $C_{d_{o}}$ outside the Group 2 tolcrances.

Once the groups have becn cstablished, $\mathrm{C}_{l_{\alpha}} \mathrm{C}_{\mathrm{d}_{0}}$, and (L/D) $\max$ are examined throughout the full fange of Mach numbers. The trends that these parameters exhibit as a function of Mach number are characterized by their inflection points, or the points at which the trends abruptly change dircction. The inflcction points of interest arc:

1. $C_{l_{\alpha}}: C_{l_{\alpha_{\max }}}, \mathrm{C}_{\boldsymbol{\alpha}_{\min }}$, and $\mathrm{C}_{\boldsymbol{\alpha}_{\text {recoverco }}}$

2. $C_{d_{0}}: M D D$ and $C_{d_{o_{\max }}}$

3. (L/D) $)_{\text {max }}$ : maximum value of $(L / D)_{\max }$

4. $\mathrm{Cl}_{l_{\text {max }}}$ : maximum valuc of $\mathrm{Cl}_{\text {max }}$

The accuracy with which these inflection points can bc cstimated, in addition to the continuous and unscattcred behavior of the data between the inflection points, are indications of data consistency.

It is important to realize that the groups are defined at low specds for a given range of Rcynolds number. This docs 
not ensure that the data in any given group will retain the same accuracy at higher specds. It is thereforc important to plot all groups throughout the full range of Mach numbers and check the consistency of the data both within the individual groups and among the groups themselves.

\section{Results}

The methodology described in the previous section was applied to the data from the experiments for both airfoils. The results of the evaluation of the data are presented in this section. Table 2 lists pertinent information about the wind tunncl facilitics used in all ninc experiments, tunncl wall corrections, and known accuracies of experiments that gencrated the NACA 0012 data previously cvaluated by McCroskey.

\section{SC1095 Airfoil}

Evaluation of $\beta C_{l_{\alpha}}$ - Figure 3 shows derived $\beta C_{l_{\alpha}}$ values from the experiments plotted versus $\log \left(\mathbf{R}_{\mathbf{c}}\right)$. Figurc 4 shows a log curve fit of the data only between $0.10<\beta C_{l_{\alpha}}<2 \pi$, along with Group 1 and Group 2 tolerances. Balance data from Experiment 2 and pressure data from Experiments 3 and 6 values are within the Group 2 tolcrance; however, nonc of the experiments are consistently within the Group 1 tolcrance. The implication is that Expcriments 2 (balance), 3, and 6 produced Group 2 quality lift coefficient data because the derived $\beta C_{l_{\alpha}}$ values are within the Group 2 tolerance.

Evaluation of $\mathbf{C}_{\mathbf{d}_{\mathbf{0}}}$ - Figure 5 shows $\mathrm{C}_{\mathbf{d}_{0}}$ values from the expcriments plottcd versus $\log \left(R_{\mathrm{e}}\right)$, along with a $\log$ curve fit of that data, and Group 1 and Group 2 tolcrances. Wakc drag data from Expcriments 1, 4, 5a, 6 , and 8 appear to be within or very near the Group 1 tolerances. Wake drag data from Experiments 2, 3, 5h, and 9 are all within the Group 2 tolerances. The implication is that all of the expcriments produced Group 2 quality drag cocfficient data becausc the $\mathrm{C}_{\mathrm{d}_{\mathrm{o}}}$ valucs arc within the Group 2 tolcrancc.

Groupings- Based entirely on the above evaluations of $\beta C_{l_{\alpha}}$ and $C_{d_{o}}$ as presented in figures 3 through 5 the groupings for the $\mathrm{SC} 1095$ data are:

Group 1 None

Group 2 Expcriments 2 (balance and wake drag), 3, and 6
Group 3 Experiment 1, 2 (pressure), 4, 5, 8, and 9

Group 4 None

Results for $\mathrm{C}_{l_{\alpha}}-$ The variation of $\mathrm{C}_{l_{\alpha}}$ throughout the full range of Mach numbers is shown in figure 6, with cach group duly noted. An examination of the Group 2 data reveals that there is a smooth and consistent trend in the variation of $C_{l_{\alpha}}$ with Mach number up to $M=0.84$. This trend is noticeably different than that exhibited by the Group 3 data, and less scattcred than the Group 3 data as wcll. A maximum value of $\mathrm{C}_{\boldsymbol{l}}$ occurs at $\mathrm{M}=0.84$ and a minimum value occurs at $M=0.90$, with a small recovery at speeds greater than $M=0.95$. Maximum, minimum, and recovered values of $\mathrm{C}_{l_{\alpha}}$ can be roughly estimated from the data shown in figure 6 . The McCroskcy-Smith expression supcrimposed on figure 6 will be discussed in the next section.

In summary, no lift coefficient data exist beyond $M=1.10$, the best lift coefficient data available are found to be Group 2 quality, and that the data are only consistent at speeds up to $\mathrm{M}=0.84$.

Results for $\mathbf{C}_{\mathbf{d}_{\mathbf{0}}}-$ The variation of $\mathrm{C}_{\mathrm{d}_{\mathbf{o}}}$ throughout the full range of Mach numbers is shown in figure 7 , with cach group duly noted. There is a consistent trend in the variation of the Group $2 \mathrm{C}_{\mathrm{d}_{\mathrm{o}}}$ with Mach number up to $M=0.80$. Experiment 8 balance data appear to be higher than the established trend beyond $\mathrm{M}=0.70$. A maximum value of $C_{d_{0}}$ can bc roughly cstimated at $M=0.98$. The McCroskcy-Smith expression supcrimposed on figurc 7 will be discussed in the next section.

In summary, no drag coefficient data exist beyond $M=1.10$, the best drag coefficient data available are found to be Group 2 quality, and the data arc only consistent at specds up to $\mathrm{M}=0.80$.

Results for (L/D) $\max$ and $C_{l_{\max }}$ Figurcs 8 and 9 show that (L/D) $)_{\max }$ and $C_{l_{\text {max }}}$ data from Expcriments 2 (balance and wake drag), 3 , and 6 are consistent at speeds between $0.50<M<0.84$. However, scatter below $M=0.5$ is cvident. McCroskcy showed that good data tend to exhibit high (L/D) $\max$ and $\mathrm{C}_{l_{\max }}$ values at low spccds. (L/D) max $_{\text {ax }}$ and $C_{l_{\text {max }}}$ data from Expcriment 3 data were noticeably higher at low speeds than the other experiments that produced Group 2 quality data. Based on these figures, it appears that (L/D) $\max$ and $C_{I_{\max }}$ occur at roughly $M=0.3$. 
The inflection points of interest for $\mathrm{C}_{l_{\alpha}}, \mathrm{C}_{\mathrm{d}_{0}}$, (L/D) max, and $\mathrm{Cl}_{l_{\max }}$ for the SC1095 airfoil data are given in table 3.

\section{SC1094R8 Airfoil}

Evaluation of $\beta C_{l_{\alpha}}-$ Figure 10 shows derived $\beta C_{l_{\alpha}}$ values from the experiments plotted versus $\log \left(R_{e}\right)$. Figure 11 shows a log curve fit of the data within $0.10<\beta C_{l_{\alpha}}<2 \pi$, along with Group 1 and Group 2 tolerances. Some of the data from cach experiment are outside the Group 2 tolerances. At least half of the balance data from Experiment 8 and half of the pressure data from Experiments 3, 4, and 6 are scattered within the Group 2 tolerances. None of the experiments are consistently within the Group 1 tolcrances. It can be concluded that all of these experiments produced a certain amount of Group 2 quality lift cocfficient data becausc the derived $\beta C_{l_{\alpha}}$ values are within the Group 2 tolerance.

Evaluation of $\mathbf{C}_{\mathbf{d}_{\mathbf{0}}}$ - Figure 12 shows $C_{d_{0}}$ values from all the experiments plotted versus $\log \left(R_{e}\right)$, along with a $\log$ curvc fit of that data, and Group 1 and Group 2 tolcrances. Most or all of the data from Expcriments 3, 6, and 8 arc within the Group 2 tolcrances. Data from Experiment 8 are scattered, with a few points outside the Group 2 tolerance boundary on the high side. Data from Experiment 4 were not used in deriving the log curve fit and arc outside of the Group 2 tolcrancc. The implication is that Expcriments 3, 6, and 8 produccd a certain amount of Group 2 quality drag cocfficicnt data bccausc the $\mathrm{C}_{d_{0}}$ values are within the Group 2 tolerance.

Groupings- Based entirely on the evaluation of $\beta \mathrm{C}_{l_{\alpha}}$ and $\mathrm{C}_{d_{\mathrm{o}}}$ as presented in Figures 10 through 12 the groupings for the SC1094R8 data arc

\section{Group 1 Nonc}

Group 2 Expcriments 3, 6, and 8

Group 3 Experiment 4

Group 4 None

Results for $\mathrm{C}_{l_{\alpha}}$ - The variation of $\mathrm{C}_{l_{\alpha}}$ throughout the full range of Mach numbers is shown in figure 13. An cxamination of the Group 2 data reveals that there arc slightly conflicting trends in the variation of $\mathrm{C}_{\boldsymbol{\alpha}}$ with Mach number. Experiment 6 values tend to be higher than the trend established by the other experiments below $M=0.60$. A maximum value occurs at $M=0.83$, but no minimum or recovered valucs can be established. The data tend to be more scattered beyond $M=0.70$ than at lower speeds, regardless of the groupings. The Smith expression superimposed on figurc 13 will be discussed in the next section.

In summary, no lift cocfficient data exist beyond $M=0.90$, the best lift coefficient data available are Group 2 quality, and these data are only consistent at speeds up to $M=0.70$.

Results for $C_{d_{0}}-$ The variation of $C_{d_{0}}$ throughout the full range of Mach numbers is shown in figure 14. There are conflicting trends in the variation of $C_{d_{0}}$ with Mach number beyond $M=0.70$. Wake data from Experiment 6 , and to a lesser extent from Experiments 3 and 8, exhibit lower drag values than the balance data from Experiment 8 . Figure 14 also shows that some Experiment 8 wake drag data are high at low specds, and those data points correspond to the high drag values noted in figure 12. A maximum value of $C_{d_{0}}$ cannot be determined. The Smith expression superimposed on figure 14 will be discussed in the next section.

In summary, no drag cocfficicnt data cxist bcyond $M=0.90$, the best drag cocfficient data available arc Group 2 quality, and the data are only consistent at specds up to $M=0.70$.

Results for $(\mathrm{L} / \mathrm{D})_{\max }$ and $\mathrm{C}_{\boldsymbol{I}_{\max }}$ - Figures 15 and 16 show (L/D) $\max$ and $C_{l_{\max }}$ data, respectively, from all the expcriments. These data are only consistent at specds between $0.60<M<0.84$. Scatter below $M=0.6$ is cvident. Experiment 6 again appears to exhibit a different $(L / D)_{\max }$ and $C_{l_{\max }}$ trend than the other experiments, which all tend to be in better agreement. Experiments 3 and 8 exhibit slightly higher values of (L/D) $\max$ and $\mathrm{C}_{I_{\text {max }}}$. Based on thesc figures it appcars that (L/D) $\max$ and $C_{l_{\max }}$ occur at roughly $\mathrm{M}=0.3$.

The inflection points of interest for $C_{l_{\alpha}}, C_{d_{o}}$, (L/D) max and $\mathrm{C}_{l_{\text {max }}}$ for the SC1094R8 airfoil data are given in table 3.

The results of this evaluation show that none of the cxperiments produced Group 1 quality data. Some of the expcriments produced Group 2 quality data. Experiment 3 produced Group 2 quality data for both the SC1095 and the SC1094R8 airfoils. Experiment 8 produced Group 2 quality data for the SC1094R8 airfoil. The SC1095 data was found to be consistent up to $M=0.84$ for lift cocfficient and $M=0.80$ for drag cocfficicnt. The SC1094R8 data was found to be consistent up to $\mathrm{M}=\mathbf{0 . 7 0}$ for both lift and drag cocfficient, except for some scattered drag data at low speeds. Other 
experiments that produced Group 2 quality data were found to exhibit slightly different trends, inconsistencies, or lower values of (L/D) $\max$ and $C_{l_{\max }}$ relative to the aforementioned experiments.

During the initial phases of this evaluation, the experimenters responsible for the publication of the SC1095 and SC1094R8 data were contacted. They were sent some preliminary results and were asked to comment on those results. The following responses were obtained and were factored into the results presented in figures 3 through 16 .

1. In general, at low drag levels, a balance sized to have high drag level capability does not give adequate resolution or precision.

2. In transonic or rotational flow balance drag data can be morc accuratc than the total probes of a wakc rakc because a rake can not capture all of the losscs.

3. When experimental angle-of-attack increments are too coarse to accurately derive reasonable values for $C_{d_{0}}$, assume that $C_{d_{0}}=C_{d_{\alpha}=0}$. Note that the zero-lift angle of attack for the SC1095 and SC1094R8 arc $-0.3^{\circ}$ and $-1.4^{\circ}$, respectively (ref. 11).

4. Intcgration of surfacc pressurcs on a model with a limited number of pressure taps is generally inaccurate.

5. Tunnel wall porosity affects $C_{l_{\alpha}}$ and $C_{l_{\max }}$ and is discussed in the published report for Experiment 5

(rcf. 5).

\section{Discussion}

Discussion is warranted on the Group 1 and Group 2 tolerances relative to accuracies in experimental measurements. To illustratc this, consider the derivation of ift from mcasurcd data as

$$
\mathrm{L}_{\text {mcasurcd }}=\mathrm{C}_{l_{\text {measured }}} \frac{1}{2} \rho \mathrm{V}^{2} \mathrm{~S}
$$

where

$$
C_{l_{\text {measured }}}=\frac{1}{\beta C} \int_{0}^{c}\left(C_{P_{l}}-C_{P_{u}}\right) d x
$$

Assuming there are inaccuracies in the pressure transducer measurements in the form of a simple bias crror, $\mathbf{P}_{\text {crror }}$, then

$$
\begin{aligned}
C_{P_{l}} & =\frac{P_{l}-P+P_{c r r o r}}{\frac{1}{2} \rho V^{2}} \\
C_{P_{u}} & =\frac{P_{u}-P-P_{\text {error }}}{\frac{1}{2} \rho V^{2}}
\end{aligned}
$$

substituting

$$
\frac{\beta_{L_{\text {measured }}}}{S}=\frac{1}{C} \int_{0}^{c}\left(P_{l}-P_{u}\right) d x+2 P_{c r r o r}
$$

$$
\left.\frac{\beta \Delta_{L_{\text {measured }}}}{S}\right|_{\text {error }}=2 P_{\text {crror }}
$$

Note that on the UH-60 Phase II Airloads Program pressure blade, the transducer measurements are accurate to within $0.1 \%$ of their maximum range of 20 psia. Thus,

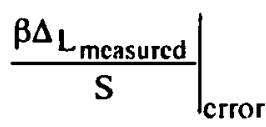

equals 0.04 psia.

Now, consider the maximum error in the calculation of lift for a given group tolerance, as follows:

$$
\begin{aligned}
\left.\frac{\beta \Delta L_{\text {Group } 1}}{S}\right|_{\text {error }}= & \left(\beta C_{l_{\alpha}}+0.0005\right) \Delta \alpha \frac{1}{2} \rho V^{2} \\
& -\left(\beta C_{l_{\alpha}}-0.0005\right) \Delta \alpha \frac{1}{2} \rho V^{2} \\
\left.\frac{\beta \Delta L_{\text {Group } 1}}{S}\right|_{\text {error }}= & 0.001 \Delta \alpha \frac{1}{2} \rho V^{2} \\
\left.\frac{\beta \Delta L_{\text {Group 2 }}}{S}\right|_{\text {crror }}= & 0.008 \Delta \alpha \frac{1}{2} \rho V^{2}
\end{aligned}
$$

Figure 17 is a plot of equations (3), (5), and (6) versus airspecd for a nominal angle-of-attack range of $1.0^{\circ}$. It can be seen that a large region exists beyond $M=0.40$, which indicates that the assumed bias error in lift measured by the UH- 60 pressure blade is smaller than the maximum possible crror that can be obtaincd when calculating lift using Group 2 wind tunncl data. This is not the casc for Group 1 quality data.

The purpose of figure 17 is to show that Group 1 data are sufficiently accurate to use in predicting UH-60 airloads. It is not meant to imply that Group 2 quality data are not sufficiently accuratc. Such a determination is dependent on many factors, such as: 
1. The desired accuracy of the predictions.

2. Aspects of the physical representation of the UH-60 that arc inaccuratc or cannot be modcled, that overshadow any inaccuracies realized by using Group 2 quality data.

3. Limitations of the comprehensive analytical model that may overshadow any inaccuracies realized by using Group 2 quality data.

Until these issues have becn resolved, it cannot be detcrmined whether Group 2 data are sufficiently accuratc for their intended use in the UH-60 model.

This last issue is the primary concern when evaluating lifting-line methods employed in comprehensive rotorcraft analyses. It is not known if current methodologies arc sensitive to crrors introduced by using Group 2 quality data. This question forms the basis for the recommendations discussed in the next section.

Also, it should be noted that consistent Group 2 quality data do not exist beyond speeds of roughly $M=0.70$ or $M=0.80$, depending on the airfoil. The advancing blade Mach numbers for the SC1095 and the SC1094R8 airfoils are 1.012 and 0.90 , respectively, at the "do not excecd" velocity of 192 knots and $20,000 \mathrm{fcct}$.

There are currently many sources of SC1095 and SC1094R8 data circulating throughout the aerospace community in a variety of different formats. Not all the sources of data are traccablc. In fact, many of those sources may be inaccuratc. An casy way to check the accuracy of those data scts would be to plot the variation of $\mathrm{C}_{l_{\alpha}}$ and $\mathrm{C}_{\boldsymbol{d}_{\mathrm{o}}}$ versus Mach number against the results presented in this report for either airfoil. Alternately, the results presented in this report can be approximated using scmi-cmpirical cxpressions developed by McCroskcy (rcf. 10) for the NACA 0012 airfoil in supcrsonic flow and by Smith (rcf. 12) for a varicty of different airfoils in subsonic flow. Correlation of the semi-empirical expressions with the results presented in this report are shown in figures 6 and 7 for the SC1095 airfoil, and in figures 13 and 14 for the SC1094R8 airfoil. The combined, or compositc, McCroskcy-Smith cxpressions uscd to gencrate the approximations shown on those figurcs are presented in the appendix.

\section{Conclusions}

The primary motivation for this cvaluation was to prepare for rigorous analysis mcthodology validation as part of the UH-60 Phase II Airloads Program. Analysis method- ology validation consists of assessing and improving state-of-the-art comprehensive analytical models through exhaustive correlative studies in performance, dynamics, and rotor structural loads and airloads. In order to productively assess and improve the theories and assumptions employed in comprehensive analytical models, accurate vehicle representations must be established. The main rotor blade airfoil section characteristics are among the most important parts of the vehicle representation. Ultimately, the improvements in analysis methodology and in vehicle representations will be judged relative to improvements in the correlation of predictions with experimental measurements.

This report shows that the most accurate data arc Group 2 quality. The experiments that generated this quality of data were performed in 1982 at the 11-Foot Wind Tunncl Facility at NASA Ames Research Center and in 1985 at the 6-Inch by 22-Inch Transonic Wind Tunnel Facility at Ohio State University. It has not been determined whether Group 2 quality data are sufficiently accuratc to use in comprehensive analytical models to predict expcrimentally measured airloads data.

Furthermore, the McCroskey methodology used to evaluate the airfoil data tend to work best when there are large amounts of data, a significant portion of which are Group 1 and 2 quality throughout the desired ranges of Mach and Reynolds numbers. Although it can be argued that a significant percentage of the data presented hercin are Group 2 quality, they are not nearly as much as desired, nor are they as consistent as desired. Therefore, it is important that further synthesis and experimentation be performed in order to generate Group 1 quality data. This conclusion warrants spccific recommendations, discussed in detail in the next scction.

\section{Recommendations}

The results presented in this report show that the most accuratc data arc Group 2 quality. It has not becn detcrmined whether this is of sufficient accuracy to use in predicting UH-60 airloads. If it is determined that the accuracy is not sufficient, then the following recommendations should be interpreted as requirements.

It is recommended that further wind tunnel cxpcrimentation be performed to obtain Group 1 quality data, and that this cffort be preceded by a synthesis similar to that performed by Tanner (ref. 13). Candidate facilities for the experimentation include those shown by McCroskey 
to produce Group 1 quality data. However, speed, angleof-attack rangc, and Rcynolds number range should bc considcred beforc choosing a wind tunncl. It is understood that the aforementioned wind tunncls may not bc able to satisfy the high speed requirement, and this should weigh heavily in the selection of a wind tunnel facility.

Further, large positive and negative angle-of-attack ranges should be considered in increments small enough to identify the exact values for $C_{l_{\text {max }}}$ and $C_{d_{o}}$. It is important that both the synthesis and expcrimentation be performed for full scale Reynolds numbers. Actual SC1095 and SC1094R8 contours as measured on the Phase II Airloads Program pressure instrumented blade should be uscd if ncw wind tunncl models of those airfoil scetions are to be fabricated. Determination of several critical parametcrs should be the priority of both the synthesis and the experimentation. These parameters include, but are not limited to, $C_{l_{\alpha_{\max }}}, \mathrm{C}_{l_{\alpha_{\min }}}$,

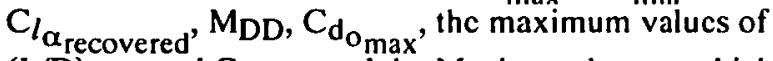
(L/D) $\max$ and $C_{l_{\text {max }}}$, and the Mach numbers at which they occur.

Finally, it is recommended that a methodology bc developed to cvaluate pitching moment cocfficient, and that the synthesis and additional cxpcrimentation treat pitching moment coefficient with the same level of detail as lift and drag coefficient.

\section{Appendix}

For the SC1095 airfoil data, the combined, or composite, McCroskey-Smith expressions are superimposed on figures 6 and 7 . In the $M \leq 0.6$ region the empirical log curve fit of the $\mathrm{C}_{l_{\alpha}}$ data is given as

$$
\beta C_{l_{\alpha}}=0.0531+0.0081 \log \left(R_{e}\right)
$$

The expressions developed by Smith for $\mathrm{C}_{l_{\alpha}}$ are $0 \leq \mathrm{M} \leq\left(\mathrm{M}_{1}=0.84\right)$

$$
\begin{aligned}
C_{l_{\alpha\left(s M_{1}\right)}=} & C_{l_{\alpha}\left(M=0, R_{c}=6 \times 10^{6}\right)}\left\{\mu+\frac{t / c}{1+t / c}[\mu(\mu-1)\right. \\
& \left.\left.+\frac{1}{4}(\gamma+1)\left(\mu^{2}-1\right)^{2}\right]\right\}
\end{aligned}
$$

and $M_{1}<M \leq 0.93$

$$
C_{l_{\alpha\left(>M_{1}\right)}}=C_{l_{\alpha\left(s M_{1}\right)}}-\frac{\partial C_{l_{a}}}{\partial M}\left(M-M_{1}\right)
$$

where

$$
\frac{\partial \mathrm{C}_{l_{\alpha}}}{\partial M}=5.4
$$

and the expression developed by McCroskey for $C_{l_{\alpha}}$ is $0.93<M \leq 1.1$

$$
C_{l_{\alpha}}=0.055\left[(\gamma+1) M^{2}(t / c)\right]^{-1 / 3}
$$

In the $M \leq 0.6$ region the log empirical curve fit of the $\mathrm{C}_{\mathrm{d}_{0}}$ data is given as

$$
C_{d_{0}}=0.0143-0.0010 \log \left(R_{c}\right)
$$

The expressions developed by Smith for $C_{d_{0}}$ arc $0 \leq \mathrm{M} \leq\left(\mathrm{MDD}_{\mathrm{DD}}=0.8\right)$

$$
C_{d_{o}}=c_{f}\left\{S_{A} \frac{L}{c}\left(1+\frac{c_{S}}{c_{F}}\right)+\frac{k\left[(0.01745)\left|\alpha_{Z L}\right|^{2.7}\right.}{c_{f_{R_{N_{o}}}}=6 \times 10^{6}}\right\}
$$

where

$$
\begin{aligned}
c_{f} & =\frac{0.455}{\left[\log \left(R_{N_{o}} \frac{1}{2} \frac{L}{c} \sqrt{S_{A}}\right)\right]^{2.58}} \\
\alpha_{Z L} & =-0.3 \mathrm{dcg} \\
S_{A} & =1.14 \\
\frac{L_{p}}{c} & =2.022 \\
\frac{c_{S}}{c_{F}} & =0.02
\end{aligned}
$$$$
R_{N_{0}}=R_{c}=6 \times 10^{6}
$$

$$
K=2.12
$$

and $\mathrm{M}_{\mathrm{DD}}<\mathrm{M}<1.0$

$$
C_{\left.d_{o}>M_{D D}\right)}=C_{d_{o}\left(M_{D D}\right)}+\frac{\partial C_{d_{o}}}{\partial M}\left(M-M_{D D}\right)
$$

where

$$
\frac{\partial \mathrm{C}_{\mathrm{d}_{\mathrm{o}}}}{\partial \mathrm{M}}=0.4
$$

and the expression developed by McCroskey for $\mathrm{C}_{\mathrm{d}_{0}}$ is $1.0 \leq M \leq 1.1$ 


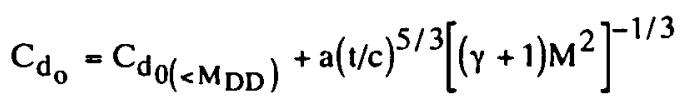

wherc

$$
\mathrm{a}=5.0
$$

For the SC1094R8 airfoil data, all of which werc subsonic data, the Smith expressions arc supcrimposed on figures 13 and 14 . In the $M \leq 0.55$ region the empirical $\log$ curve fit of the $\mathrm{C}_{l_{\alpha}}$ data is given as

$$
\beta C_{l_{\alpha}}=0.0977+0.0009 \log \left(R_{e}\right)
$$

The expressions developed by Smith for $\mathrm{C}_{l_{\alpha}}$ are $0 \leq \mathrm{M} \leq\left(\mathrm{M}_{1}=0.83\right)$

$$
\begin{aligned}
C_{l_{\alpha}}= & C_{l_{\alpha}\left(M=0, R_{c}=10^{6}\right)}\left\{\mu+\frac{t / c}{1+t / c}[\mu(\mu-1)\right. \\
& \left.\left.+\frac{1}{4}(\gamma+1)\left(\mu^{2}-1\right)^{2}\right]\right\}
\end{aligned}
$$

and $\mathrm{M}_{1}<\mathrm{M}<0.9$

$$
C_{l_{\alpha\left(>M_{1}\right)}}=C_{l_{\alpha\left(\leq M_{1}\right)}}-\frac{\partial C_{l_{\alpha}}}{\partial M}\left(M-M_{1}\right)
$$

wherc

$$
\frac{\partial \mathrm{C}_{l_{\alpha}}}{\partial M}=5.4
$$

In the $M \leq 0.55$ region, the cmpirical log curve fit of the $\mathrm{C}_{\mathrm{d}_{\mathrm{o}}}$ data is given as

$$
C_{d_{0}}=0.0146-0.0009 \log \left(R_{c}\right)
$$

The cxpressions developed by Smith for $\mathrm{C}_{\mathrm{d}_{\mathrm{O}}}$ arc $0 \leq \mathrm{M} \leq\left(\mathrm{M}_{\mathrm{DD}}=0.7\right)$

$$
C_{d_{o}}=c_{f}\left\{S_{A} \frac{L}{c}\left(1+\frac{c_{s}}{c_{F}}\right)+\frac{k\left[(0.01745)|| \alpha_{Z L} \mid\right]^{2.7}}{c_{f_{R_{N_{O}}}}=6 \times 10^{6}}\right\}
$$

where

$$
\begin{aligned}
\mathrm{c}_{\mathrm{f}} & =\frac{0.455}{\left[\log \left(\mathrm{R}_{\mathrm{N}_{\mathrm{o}}} \frac{1}{2} \frac{\mathrm{L}}{\mathrm{c}} \sqrt{\mathrm{S}_{\mathrm{A}}}\right)\right]^{2.58}} \\
\alpha_{\mathrm{ZL}} & =-1.4 \mathrm{deg} \\
\mathrm{S}_{\mathrm{A}} & =1.14 \\
\frac{\mathrm{L}_{\mathrm{p}}}{\mathrm{c}} & =2.022 \\
\frac{\mathrm{c}_{\mathrm{S}}}{\mathrm{c}_{\mathrm{F}}} & =0.02 \\
\mathrm{R}_{\mathrm{N}_{\mathrm{o}}} & =\mathrm{R}_{\mathrm{e}}=6 \times 10^{6} \\
\mathrm{~K} & =2.12 \\
\text { and } \mathrm{M}_{\mathrm{DD}}<\mathrm{M} & <0.9 \\
\mathrm{C}_{\mathrm{d}_{\mathrm{O}}\left(>\mathrm{M}_{\mathrm{DD}}\right)} & =\mathrm{C}_{\mathrm{d}_{\mathrm{o}}\left(\leq \mathrm{M}_{\mathrm{DD}}\right)}+\frac{\partial \mathrm{C}_{\mathrm{d}_{\mathrm{o}}}}{\partial \mathrm{M}}\left(\mathrm{M}-\mathrm{M}_{\mathrm{DD}}\right)
\end{aligned}
$$

where

$$
\frac{\partial C_{d_{0}}}{\partial M}=0.15
$$

The above expressions compare well with the noted trends of $C_{l_{\alpha}}$ and $C_{d_{o}}$ versus Mach number for both the airfoils, with a small discrepancy noted in $\mathrm{C}_{l_{\alpha}}$ for the SC1094R8 data between $M=0.5$ and $M=0.8$. These expressions are meant only to quantify observed trends. An analysis of the correlation is not within the scope of this paper. 


\section{References}

1. Griffin, T.: Wind Tunncl Tests of Sikorsky SC1095 Two Dimensional Airfoil with Various Surface Irregularities. UARL Report M432170-1, October 17, 1973.

2. Vogl, P.: An Evaluation of NACA 0012 and SC 1095 Airfoil Tests in the UTRC Large Subsonic Wind Tunncl. UTRC75-121, December 31, 1975.

3. Lednicer, D.; and Owen, S.: An Evaluation of Eleven Helicopter Airfoil Sections in the Ohio State University $6 \times 22$ Transonic Facility. SER-760603, November 15, 1985.

4. Flemming, R. J.; and Lednicer, D. A.: High Specd Icc Accrction on Rotorcraft Airfoils. NASA CR-3910, 1985.

5. Jepson, W. D.: Two Dimensional Test of Four Airfoil Configurations with an Aspect Ratio of 7.5 and a 16 inch Chord up to a Mach Number of 1.1. SER-50977, April 5, 1977.

6. Noonan, K. W.; and Bingham, G. J.: Acrodynamic Characteristics of Threc Hclicopter Airfoil Sections at Reynolds Numbers From Model Scale to Full Scale at Mach Numbers from 0.35 to 0.9. NASA TP-1701, September 1980.
7. Hicks, R. M.; and Collins, L. J.: An Evaluation of Three Helicopter Rotor Scctions. NASA TM-86719, August 1985.

8. Flemming, R. J.: An Experimental Evaluation of Advanced Rotorcraft Airfoils in the NASA Ames Eleven-Foot Wind Tunnel. NASA CR-166587, April 1982.

9. McCroskey, W. J.; McAlister, K. W.; Carr, L. W.; and Pucci, S. L.: An Experimental Study of Dynamic Stall on Advanced Airfoil Scctions. NASA TM-84245, July 1982.

10. McCroskey, W. J.: A Critical Assessment of Wind Tunnel Results for the NACA 0012 Airfoil. NASA TM-100019, Octobcr 1987.

11. Shanlcy, J. P.: Validation of UH-60A CAMRAD/JA Input Model. SER-701716, November 1991.

12. Smith, R. L.: Closed-Form Equations for the Lift, Drag, and Pitching-Moment Coefficients of Airfoil Sections in Subsonic Flow. NASA TM-78492, 1978.

13. Tanner, W. H.: Charts for Estimating Rotary Wing Performance in Hover and at High Forward Speeds. NASA CR-114, 1964. 
Table 1. SC1095 and SC1094R8 wind tunnel data reference list

\begin{tabular}{|c|c|c|c|c|}
\hline $\begin{array}{l}\text { Experiment facility } \\
\text { report no. }\end{array}$ & Mach range & $\begin{array}{c}R_{\mathbf{c}} \text { range } \\
\left(\text { range } \times 10^{6}\right)\end{array}$ & $\begin{array}{l}\text { Model and tunnel } \\
\text { dimensions }\end{array}$ & Remarks \\
\hline $\begin{array}{l}\text { Expcriment } 1 \\
\text { LSWT } 8 \mathrm{ft} \\
\text { UARL M432170-1 }\end{array}$ & $0.3-0.75$ & $2.52-4.97$ & $\begin{array}{l}b / c=2.06 \\
h / c=5.8\end{array}$ & $\begin{array}{l}\mathrm{SC} 1095 \\
\text { Limited rights data, } \\
\text { balance, wake }\end{array}$ \\
\hline $\begin{array}{l}\text { Expcriment } 2 \\
\text { LSWT } 8 \mathrm{ft} \\
\text { UTRC75-121 }\end{array}$ & $0.3-0.75$ & $2.54-4.94$ & $\begin{array}{l}b / c=7.75 \\
h / c=5.8\end{array}$ & $\begin{array}{l}\mathrm{SC} 1095 \\
\text { Limited rights data, } \\
\text { pressure, wake }\end{array}$ \\
\hline $\begin{array}{l}\text { Expcriment } 3 \\
\text { Ohio State } 6 \text { in. } \times 22 \text { in. } \\
\text { SER-760603 }\end{array}$ & $0.3-0.85$ & $2.88-7.57$ & $\begin{array}{l}b / c=3.67 \\
h / c=1.0\end{array}$ & $\begin{array}{l}\text { SC1095, SC1094R8 } \\
\text { Partial limitation, } \\
\text { pressure, including } \\
\text { tripped data }\end{array}$ \\
\hline $\begin{array}{l}\text { Experiment } 4 \\
\text { NRC high speed icing } \\
\text { facility } \\
\text { NASA CR-3910 }\end{array}$ & $0.3-0.87$ & $1.80-4.60$ & $\begin{array}{l}b / c=2.0 \\
h / c=2.0\end{array}$ & $\begin{array}{l}\text { SC1095, SC1094R8 } \\
\text { Domestic limitation, } \\
\text { pressure, wake }\end{array}$ \\
\hline $\begin{array}{l}\text { Experiment } 5 \\
\text { NSRDC } 7 \mathrm{ft} \times 10 \mathrm{ft} \\
\text { SER-50977 }\end{array}$ & $0.3-1.1$ & $1.29-3.96$ & $\begin{array}{l}b / c=7.5 \\
h / c=5.25\end{array}$ & $\begin{array}{l}\mathrm{SC} 1095 \\
\text { Balance, pressure, } \\
\text { wakc, including } \\
\text { strut data }\end{array}$ \\
\hline $\begin{array}{l}\text { Experiment } 6 \\
\text { LaRC } 6 \text { in. } \times 28 \text { in. } \\
\text { NASA TP-1701 }\end{array}$ & $0.35-0.9$ & $1.60-6.70$ & $\begin{array}{l}\mathrm{b} / \mathrm{c}=1.94 \\
\mathrm{~h} / \mathrm{c}=9.03\end{array}$ & $\begin{array}{l}\text { SC1095, SC1094R8 } \\
\text { Prcssurc, + } 3^{\circ} \text { (up) } \\
\text { TE tabs }\end{array}$ \\
\hline $\begin{array}{l}\text { Experiment } 7 \\
\qquad \text { Amcs } 2 \mathrm{ft} \times 2 \mathrm{ft} \\
\text { NASA TM- } 86719\end{array}$ & $0.2-0.88$ & $1.87-4.00$ & $\begin{array}{l}b / c=4.0 \\
h / c=4.0\end{array}$ & $\begin{array}{l}\text { SCl095 } \\
\text { Pressurc }\end{array}$ \\
\hline $\begin{array}{l}\text { Experiment } 8 \\
\qquad \begin{array}{l}\text { Ames } 11 \mathrm{ft} \\
\text { NASA CR-166587 }\end{array}\end{array}$ & $0.3-1.1$ & $3.60-6.05$ & $\begin{array}{l}\mathrm{b} / \mathrm{c}=8.21 \\
h / c=8.21\end{array}$ & $\begin{array}{l}\mathrm{SC} 1095, \mathrm{SC} 1094 \mathrm{R} 8 \\
\text { Balance, pressure, } \\
\text { wakc }\end{array}$ \\
\hline $\begin{array}{l}\text { Experiment } 9 \\
\text { Amcs } 7 \mathrm{ft} \times 10 \mathrm{ft} \\
\text { NASA TM-84245 }\end{array}$ & $0.11-0.3$ & $1.44-3.88$ & $\begin{array}{l}b / c=3.49 \\
h / c=5.0\end{array}$ & $\begin{array}{l}\text { SC1095 } \\
\text { Pressurc, wakc }\end{array}$ \\
\hline
\end{tabular}

LSWT $=$ largc-scalc wind tunncl

NSRDC $=$ Naval Ship Research and Development Center 
Table 2. Wind tunnel facility reputation and wall corrections used in the experiments

\begin{tabular}{|c|c|c|c|}
\hline Experiment & Wind tunnel & $\begin{array}{l}\text { Documented } \\
\text { rcputation }\end{array}$ & Tunnel wall corrections \\
\hline Experiment 1 & LSWT $8 \mathrm{ft}$ & Group 3 & Lincar wall corrections, solid walls \\
\hline Experiment 2 & LSWT $8 \mathrm{ft}$ & Group 3 & Linear wall corrections, solid walls \\
\hline Experiment 3 & Ohio St. 6 in. $\times 22$ in. & Group 4 & $\begin{array}{l}\text { Independent plenums for top and boltom walls, porous } \\
\text { walls }\end{array}$ \\
\hline Expcriment 4 & NRC lcing & & $\begin{array}{l}\text { Lincar plenum, surface corrections, and high turbulence } \\
\text { levels }\end{array}$ \\
\hline Expcriment 5 & NSRDC $7 \mathrm{ft} \times 10 \mathrm{ft}$ & Group 4 & $\begin{array}{l}\text { Largc lift interference, with and without wake drag } \\
\text { corrections, high porosity, and slotted walls }\end{array}$ \\
\hline Experiment 6 & LaRC 6 in. $\times 28$ in. & $\begin{array}{l}\text { Group } 4 \\
\text { (capable of } \\
\text { Group 3) }\end{array}$ & $\begin{array}{l}\text { AOA corrected, side wall boundary layer effects on shock } \\
\text { position, and } C_{l_{\max }} \text {, and slotted walls }\end{array}$ \\
\hline Expcriment 7 & Amcs $2 \mathrm{ft} \times 2 \mathrm{ft}$ & & AOA corrections and slotted walls \\
\hline Expcriment 8 & Amcs $11 \mathrm{ft}$ & & Wall corrections but nonc on $A O A$, and slotted walls \\
\hline Experiment 9 & Ames $7 \mathrm{ft} \times 10 \mathrm{ft}$ & Group 2 & Linear wall corrections, and solid walls \\
\hline
\end{tabular}

${ }^{a}$ Established by McCroskey in his evaluation of NACA 0012 data.

Table 3. Summary of results

\begin{tabular}{|c|c|c|c|c|c|c|c|c|}
\hline & & $\mathrm{C}_{\mathbf{d}_{\mathrm{O}_{\max }}}$ & $\mathrm{C}_{\mathrm{d}_{\mathrm{OM}_{\mathrm{DD}}}}$ & $(\mathrm{UD})_{\max }$ & $\mathrm{C}_{l_{\max }}$ & $\mathrm{C}_{l_{\alpha_{\max }}}$ & $\mathrm{c}_{l_{\alpha_{\min }}}$ & $\mathrm{c}_{l_{\alpha_{\text {recovered }}}}$ \\
\hline \multirow[t]{2}{*}{$\mathrm{SC} 1095$} & Value & 0.09 & 0.0075 & 105 & $(1.35)$ & $(0.24)$ & $(0.05)$ & $(0.085)$ \\
\hline & $\begin{array}{l}\text { Mach } \\
\text { number }\end{array}$ & 0.98 & 0.80 & 0.30 & 0.30 & 0.84 & 0.90 & 0.93 \\
\hline \multirow[t]{2}{*}{ SC1094R8 } & Value & $*$ & 0.0077 & (115) & $(1.75)$ & 0.20 & $*$ & * \\
\hline & $\begin{array}{l}\text { Mach } \\
\text { number }\end{array}$ & & 0.70 & 0.30 & 0.30 & 0.83 & & \\
\hline
\end{tabular}

() denotes scattcred data

* denotes no data 


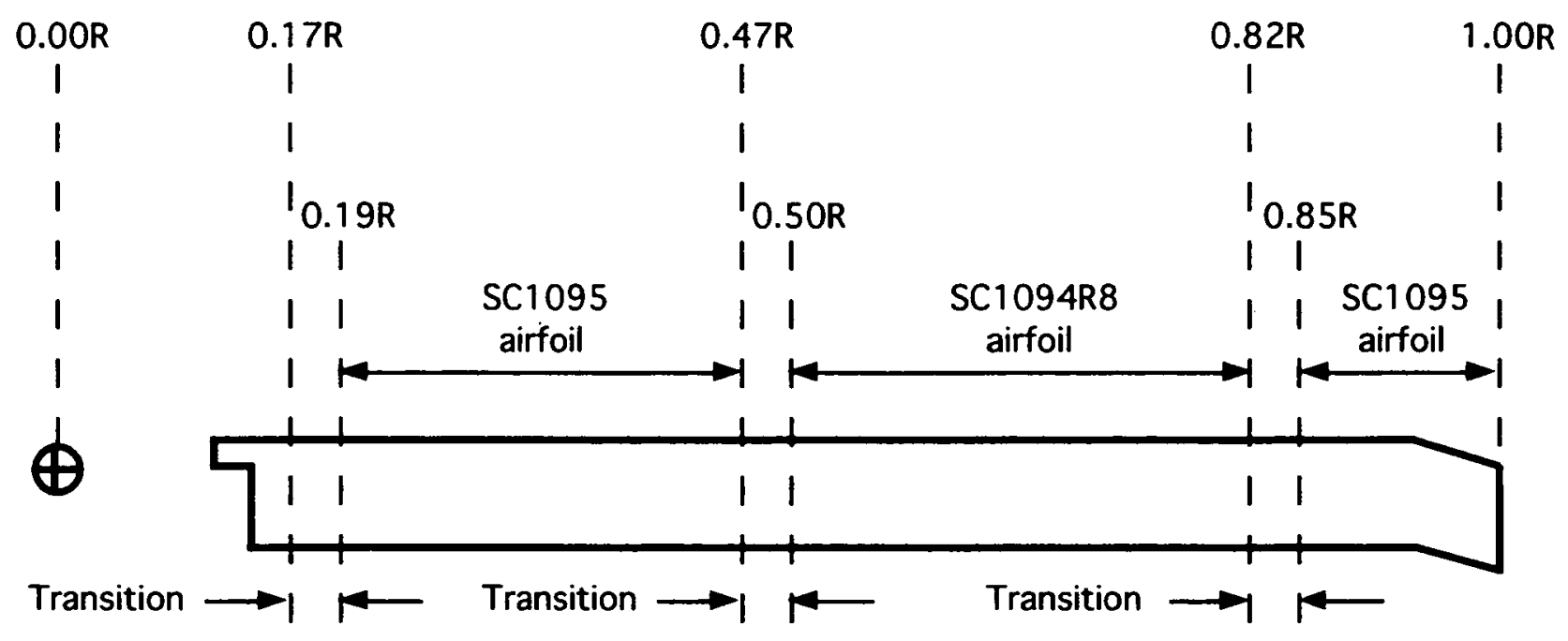

Figure 1. UH-60A Black Hawk main rotor blade airfoil section locations.

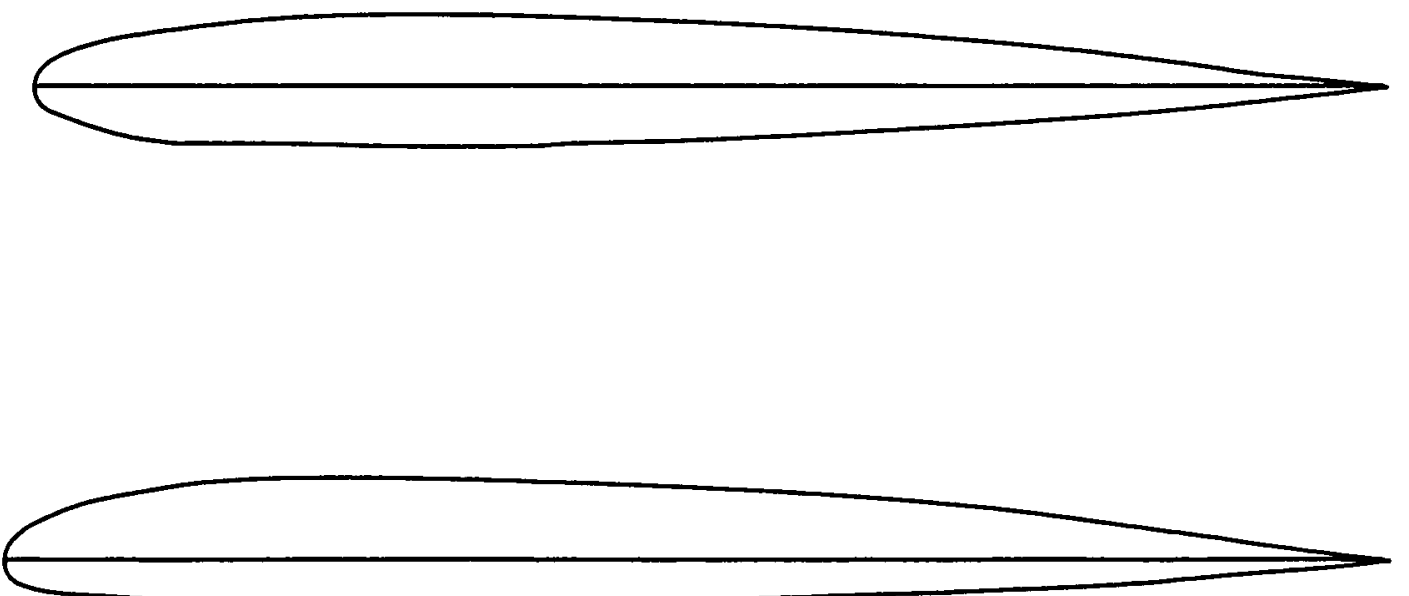

SC1095

airfoil

SC1094R8

airfoil

Figure 2. SC1095 and SC1094R8 airfoil sections. 


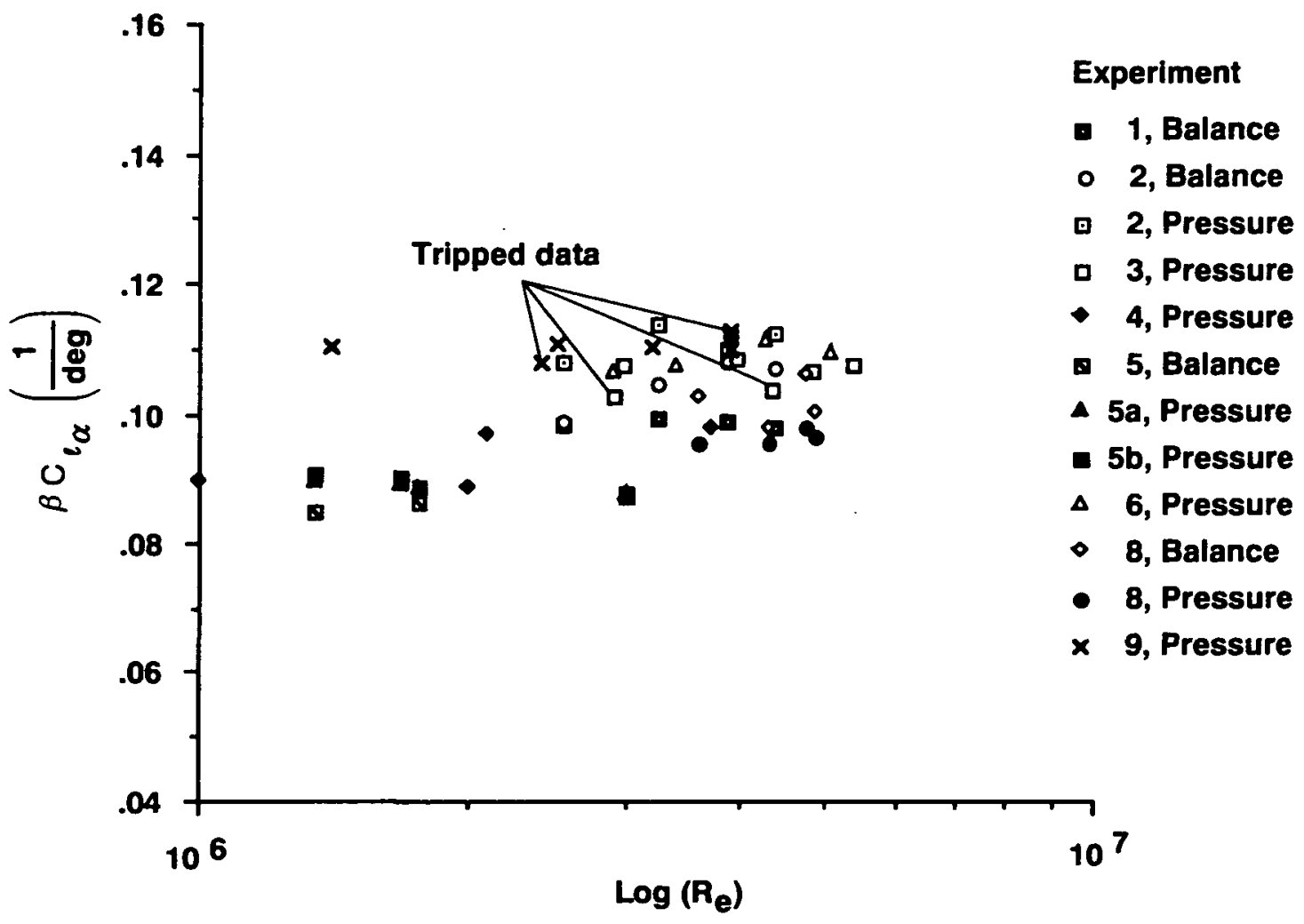

Figure 3. SC1095 Mach corrected lift curve slope versus Reynolds number, $M<0.6$.

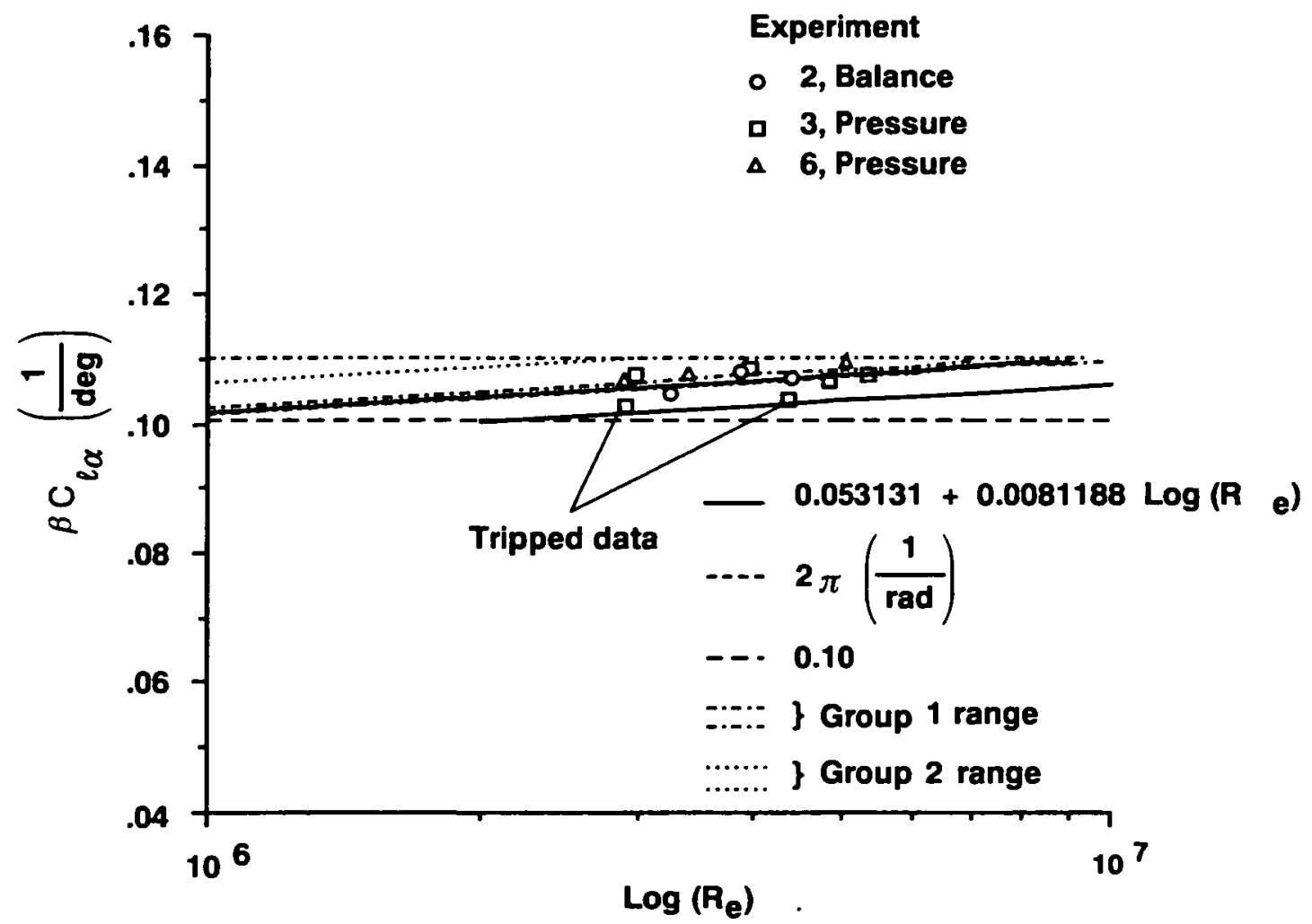

Figure 4. SC1095 Mach corrected lift-curve slope versus Reynolds number with Group 1 and Group 2 tolerances, $M<0.6$. 


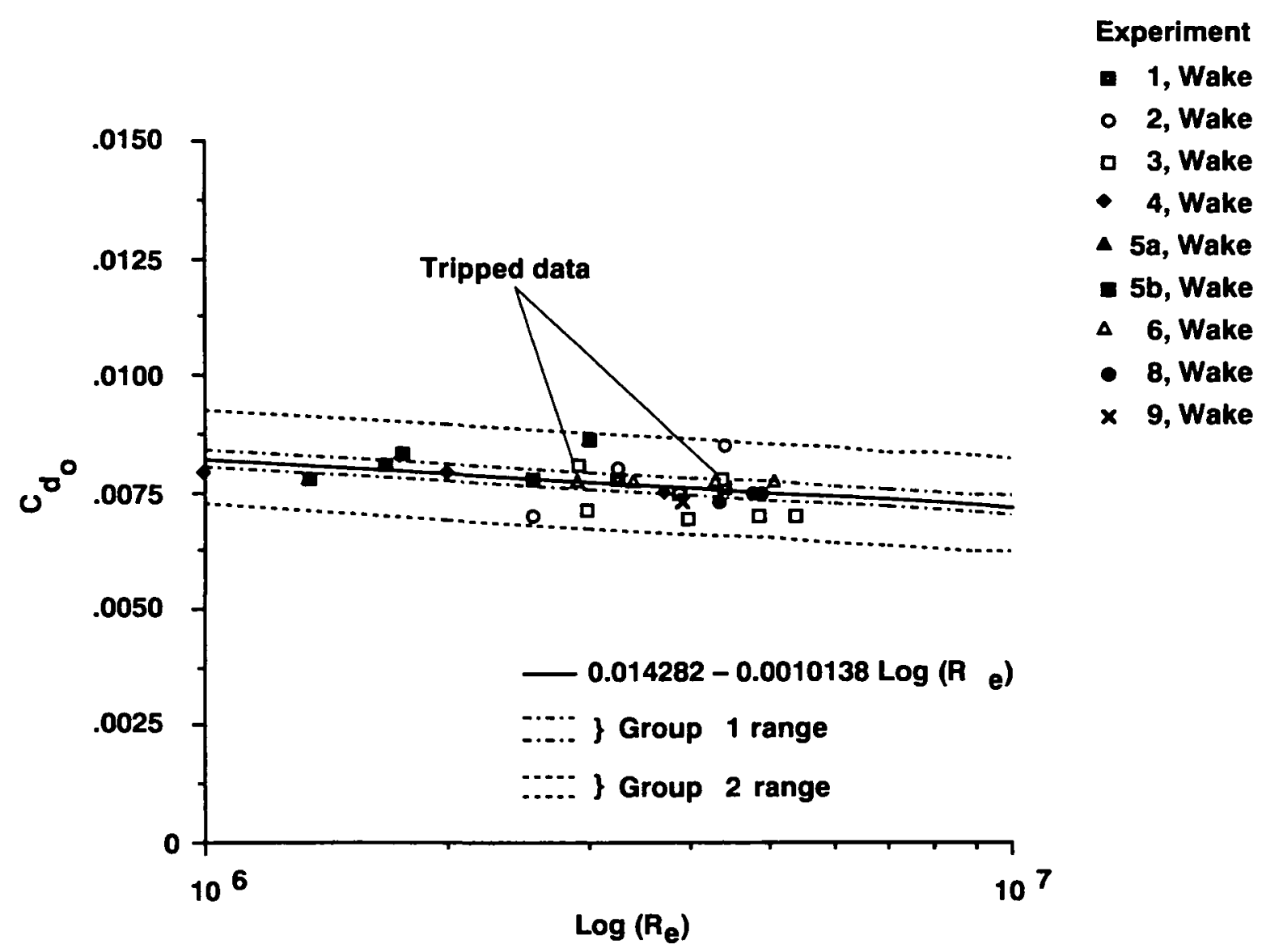

Figure 5. SC1095 drag coefficient at zero-lift versus Reynolds number with Group 1 and Group 2 tolerances, $M<0.6$.

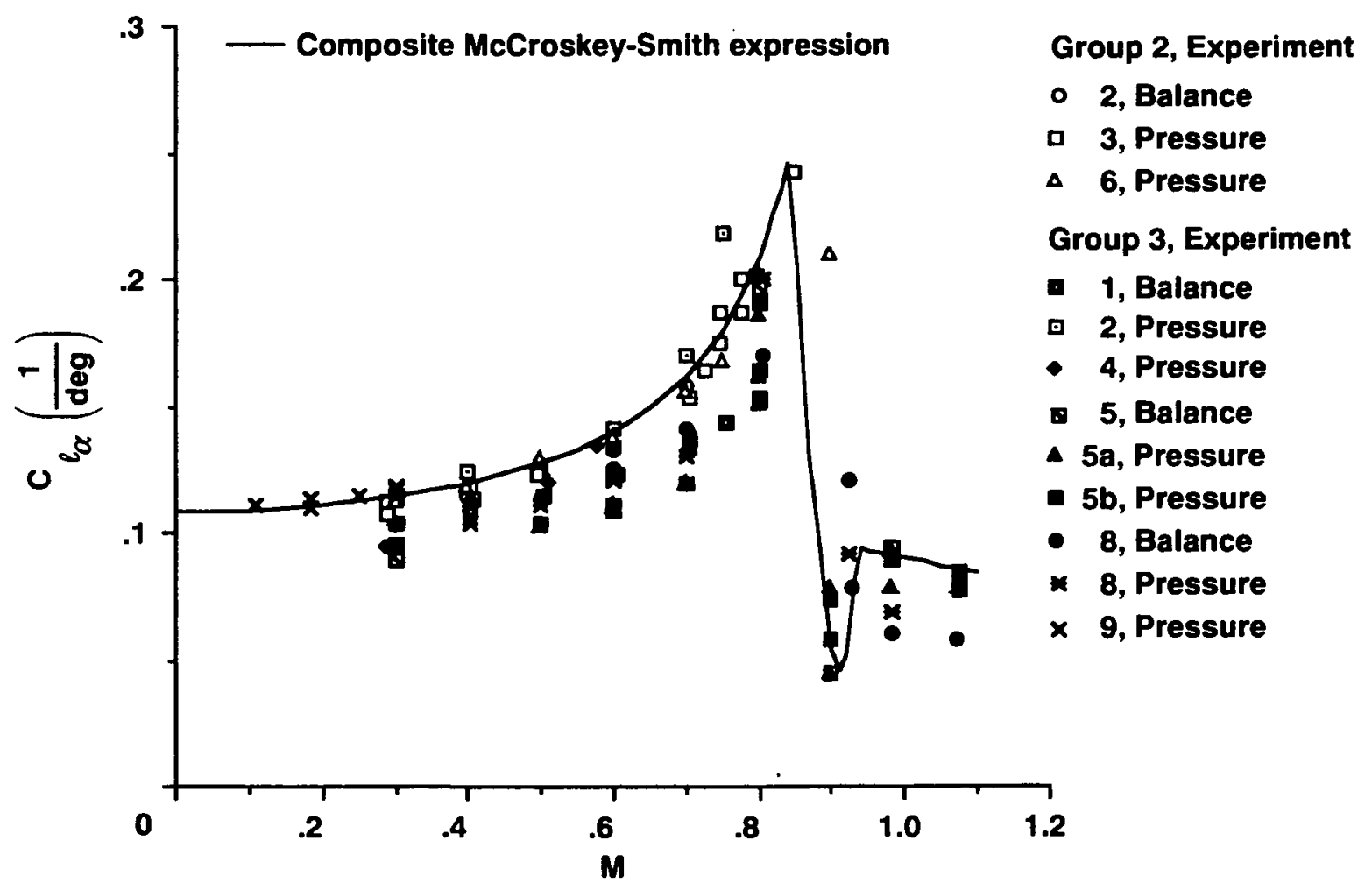

Figure 6. SC1095 lift-curve slope versus Mach number. 


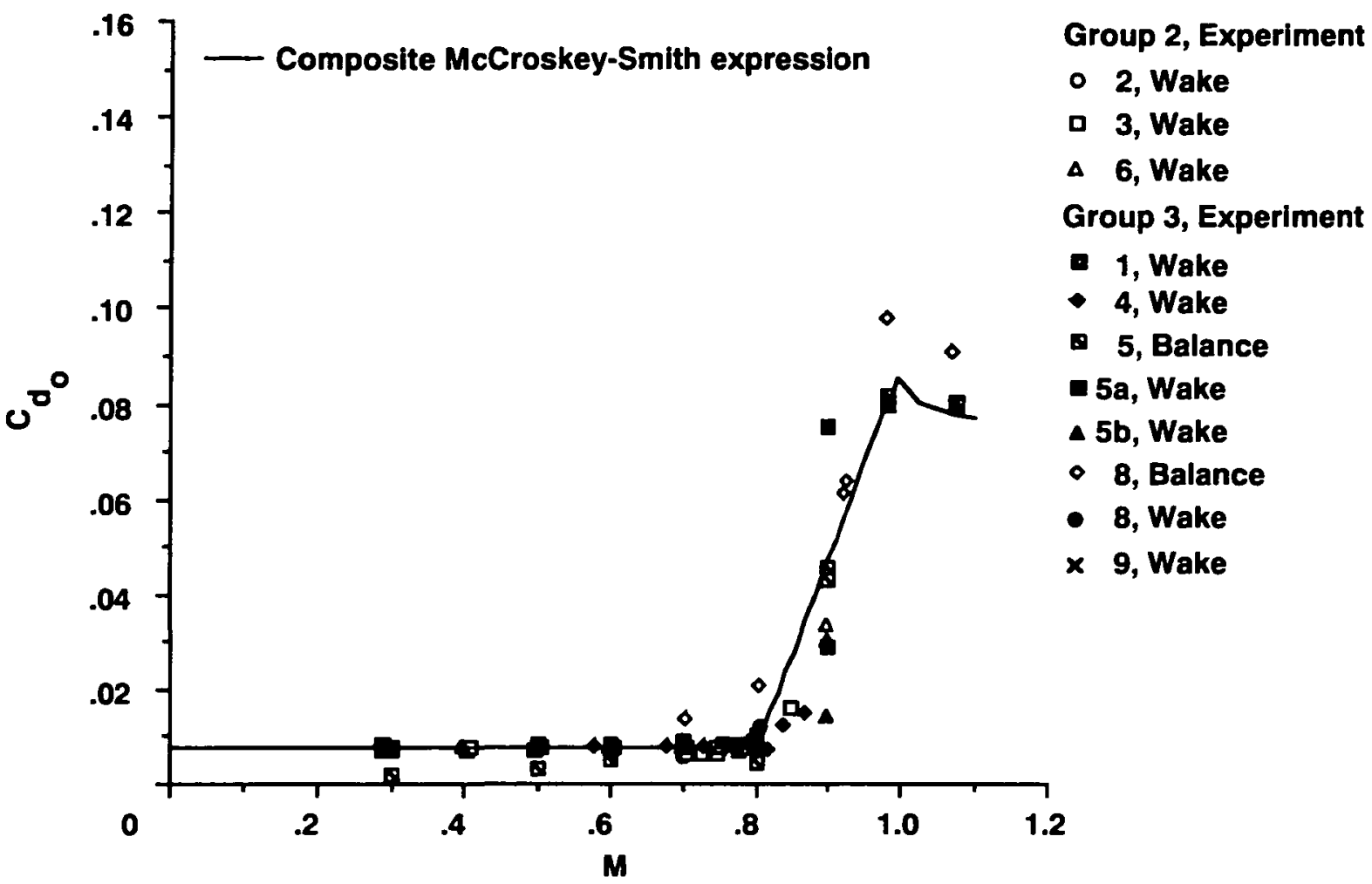

Figure 7. SC1095 drag coefficient at zero lift versus Mach number.

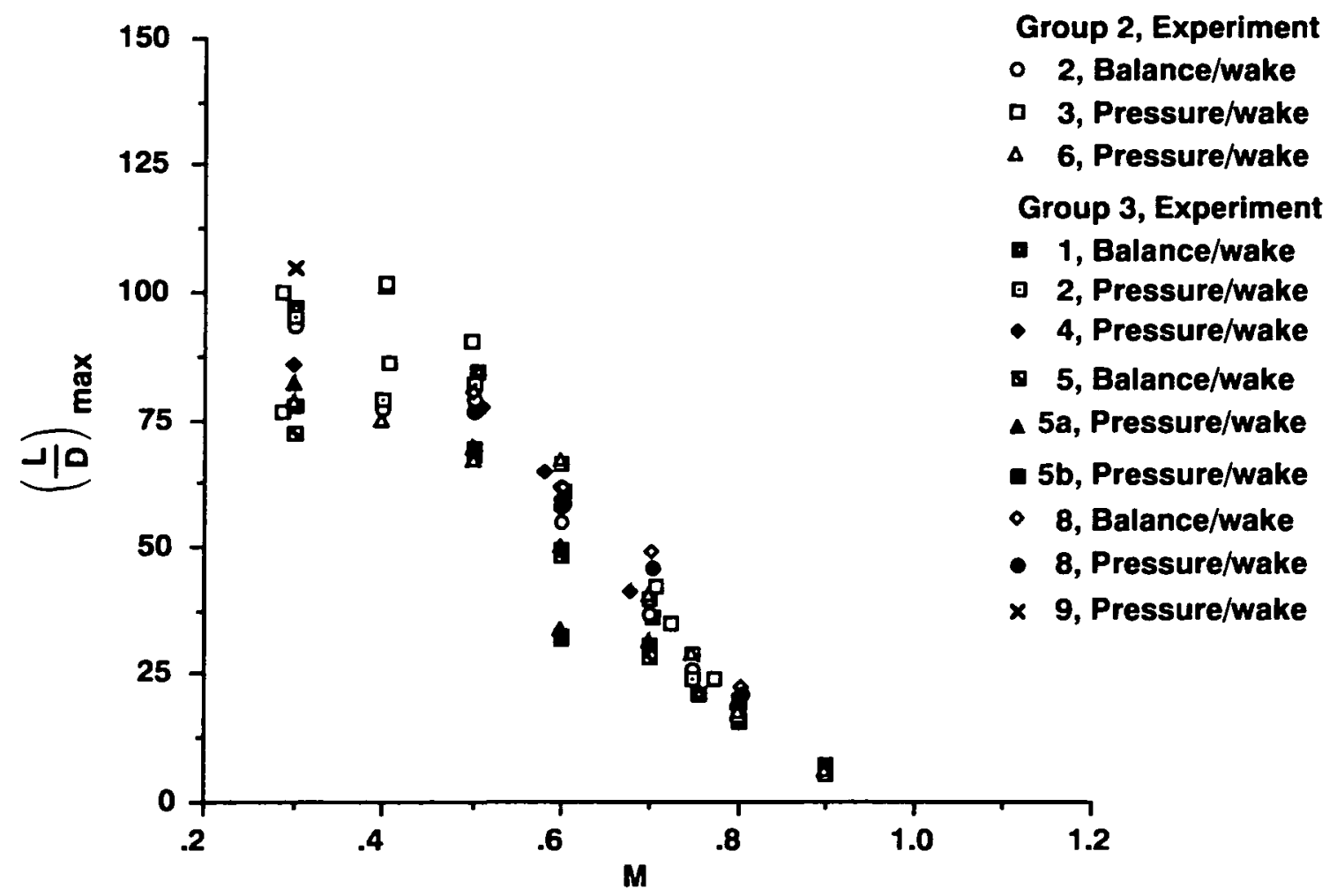

Figure 8. SC1095 maximum lift-to-drag ratio versus Mach number. 


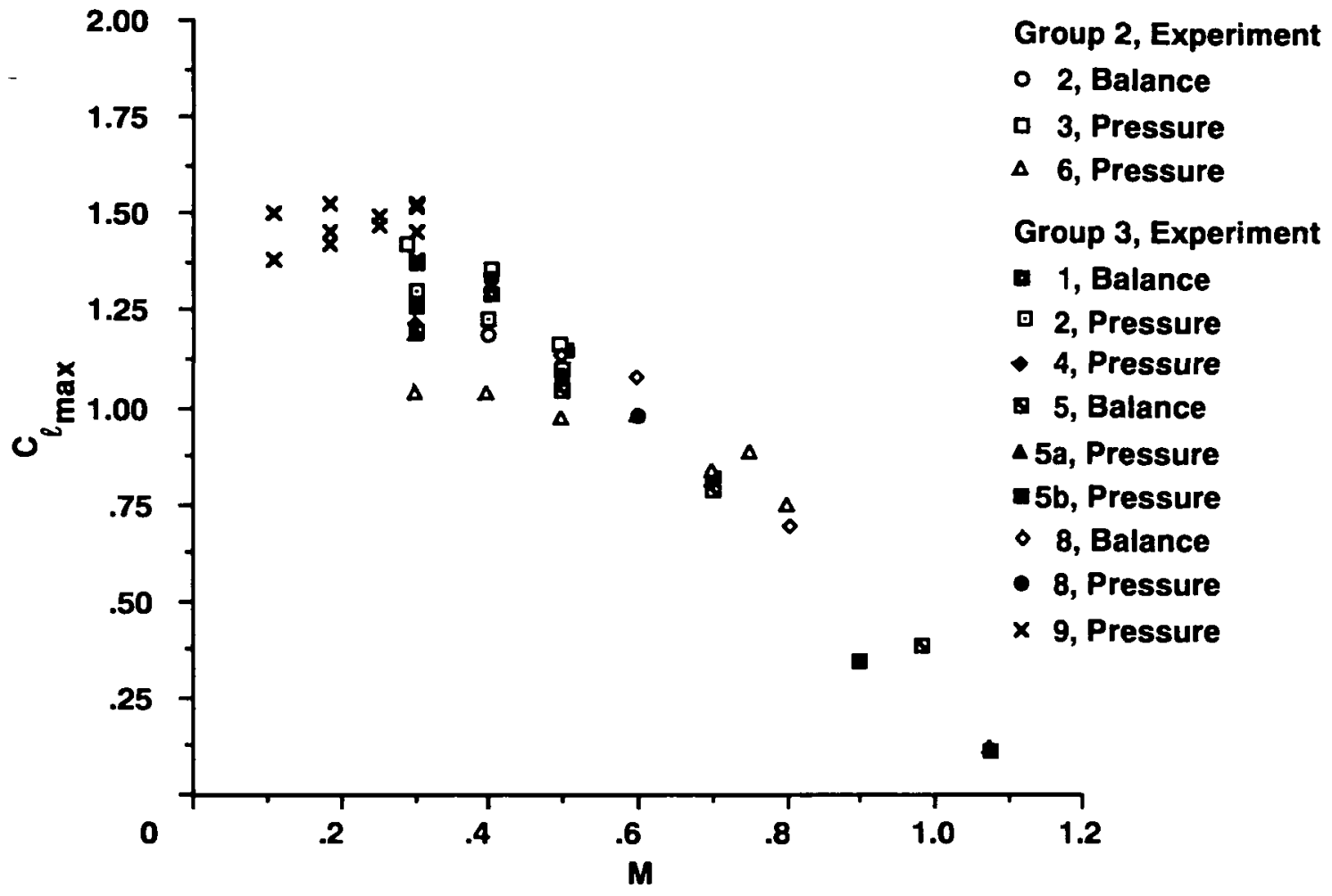

Figure 9. SC1095 maximum lift coefficient versus Mach number.

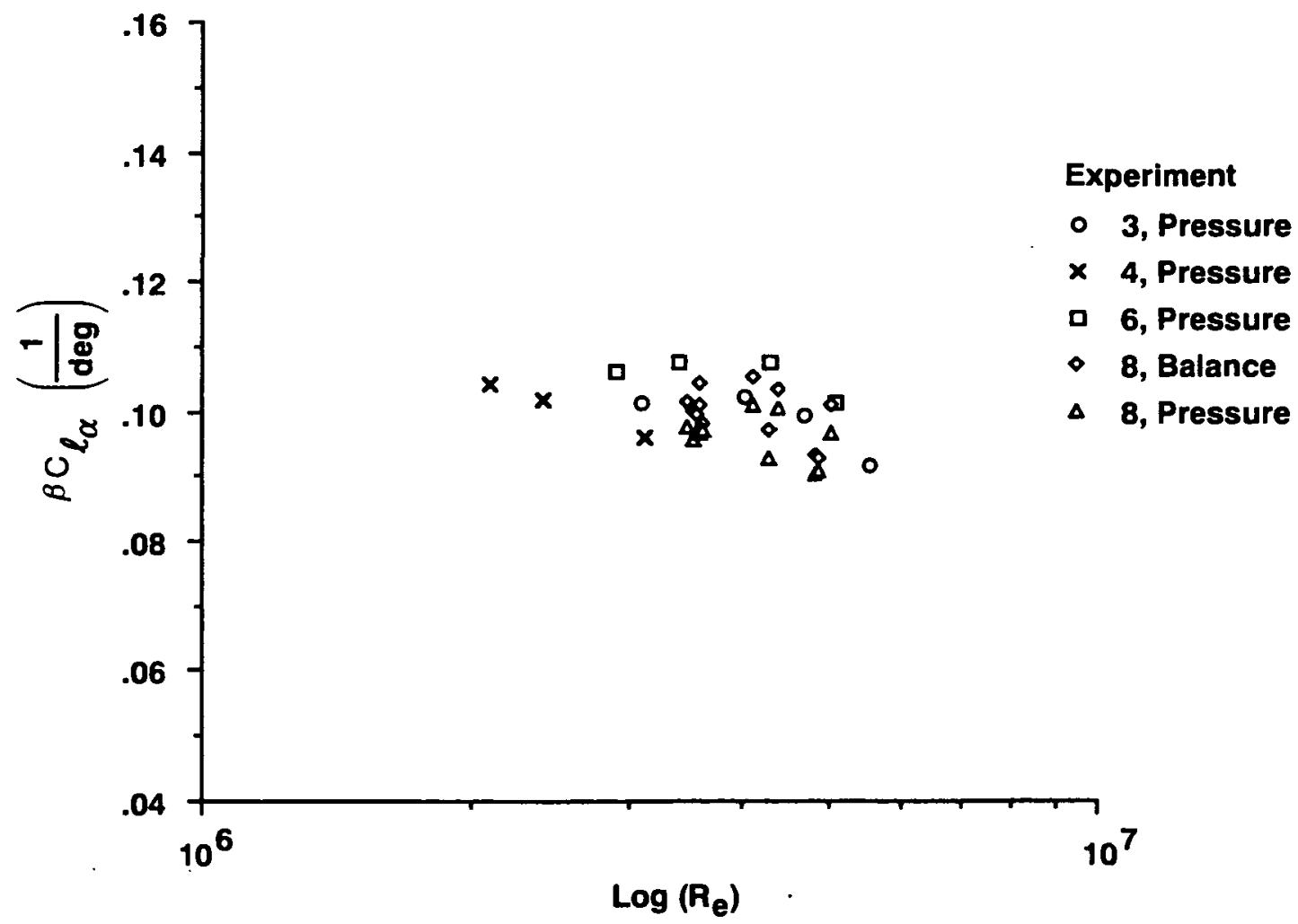

Figure 10. SC1094R8 Mach corrected lift curve slope versus Reynolds number, $M<0.55$. 


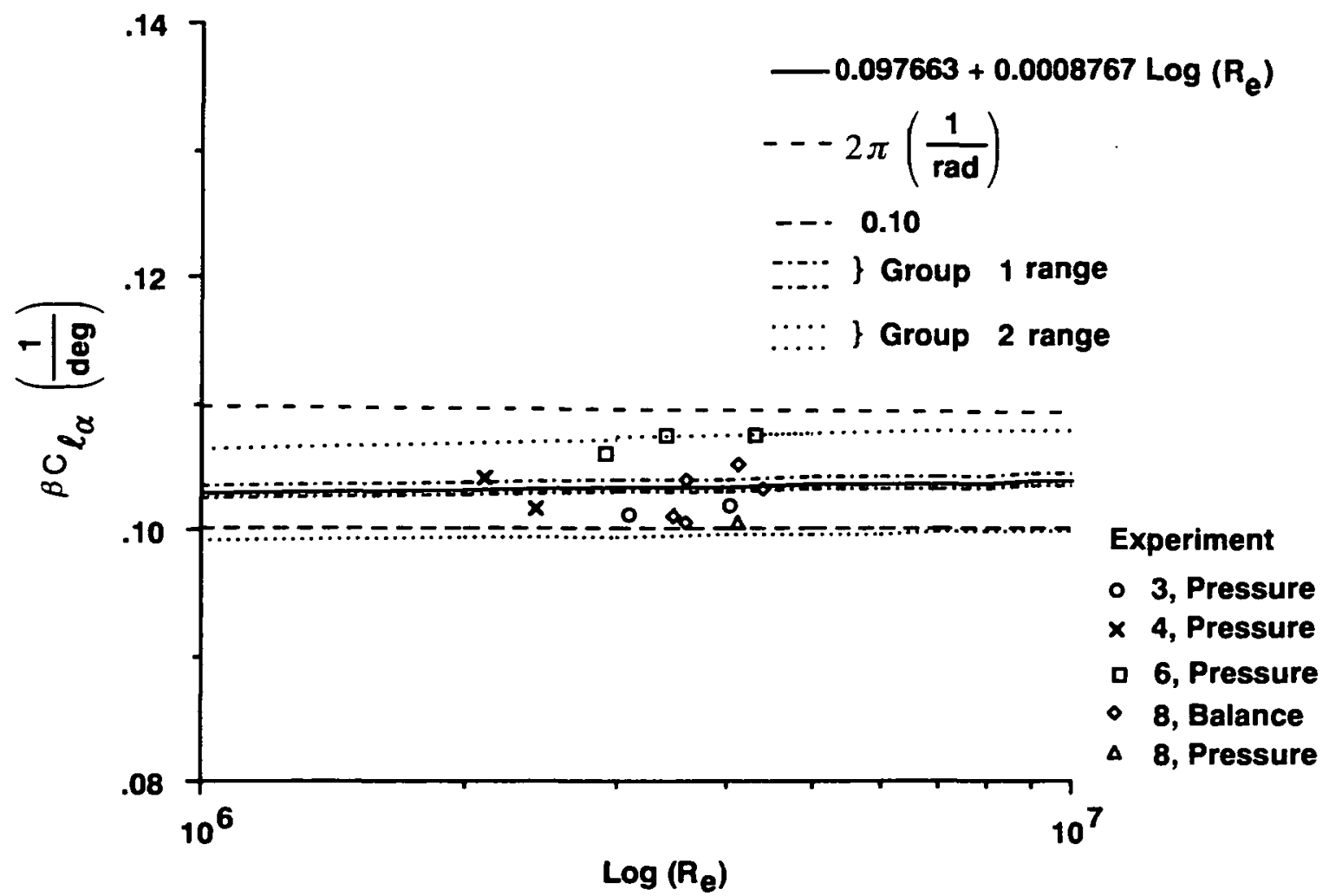

Figure 11. SC1094R8 Mach corrected lift-curve slope versus Reynolds number with Group 1 and Group 2 tolerances, $M<0.55$.

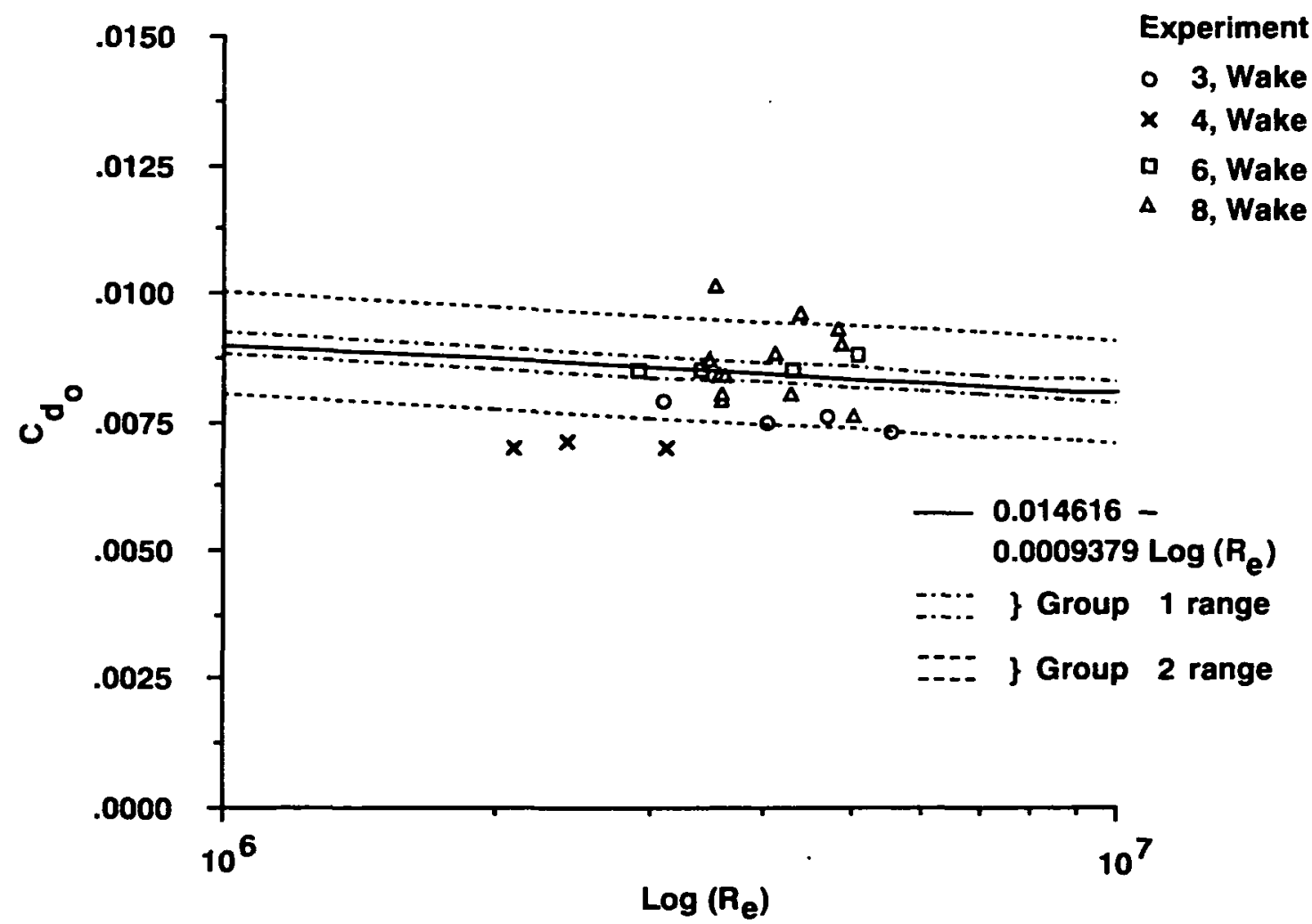

Figure 12. SC1094R8 drag coefficient at zero-lift versus Reynolds number with Group 1 and Group 2 tolerances, $M<0.55$. 


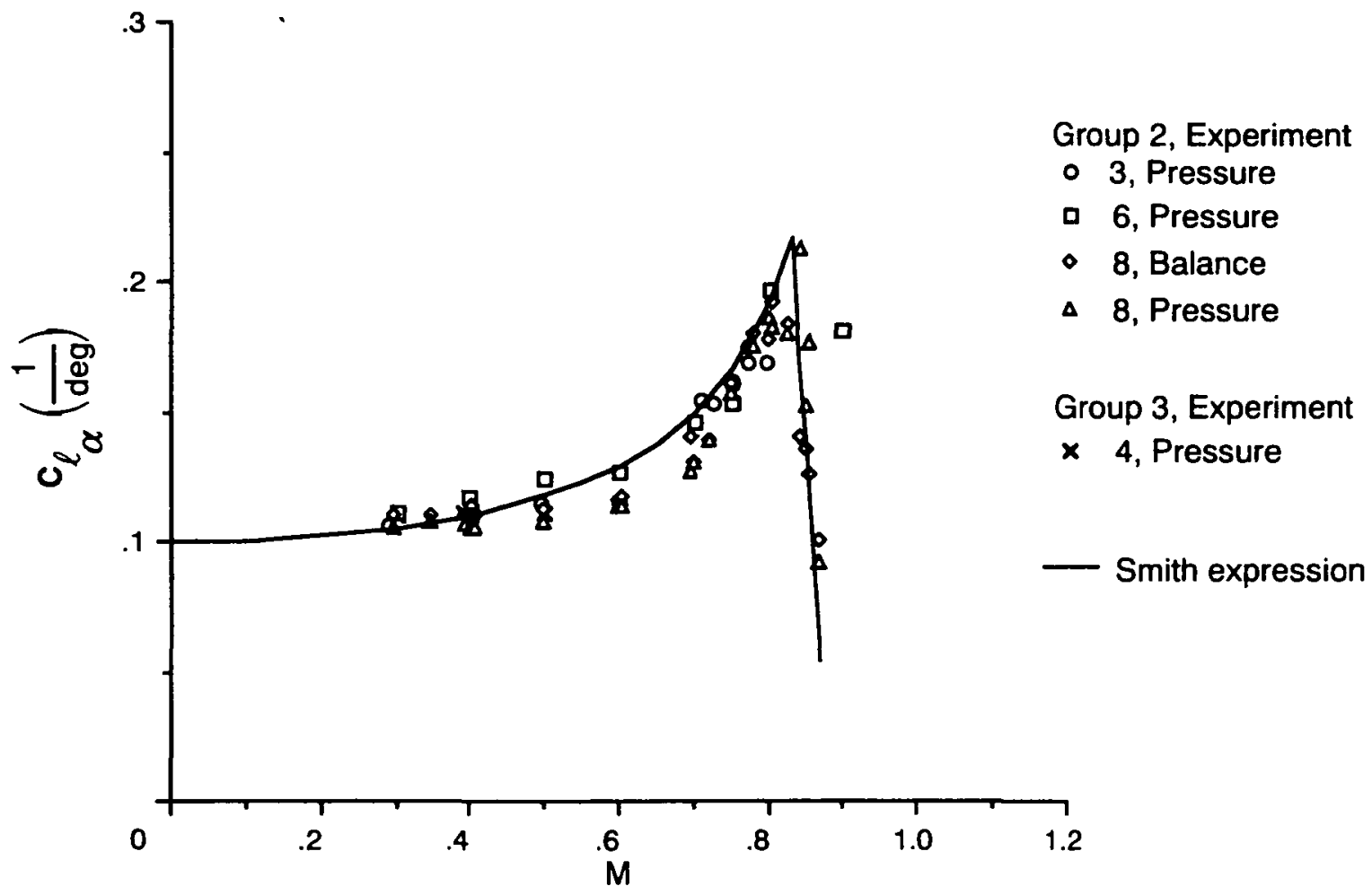

Figure 13. SC1094R8 lift-curve slope versus Mach number.

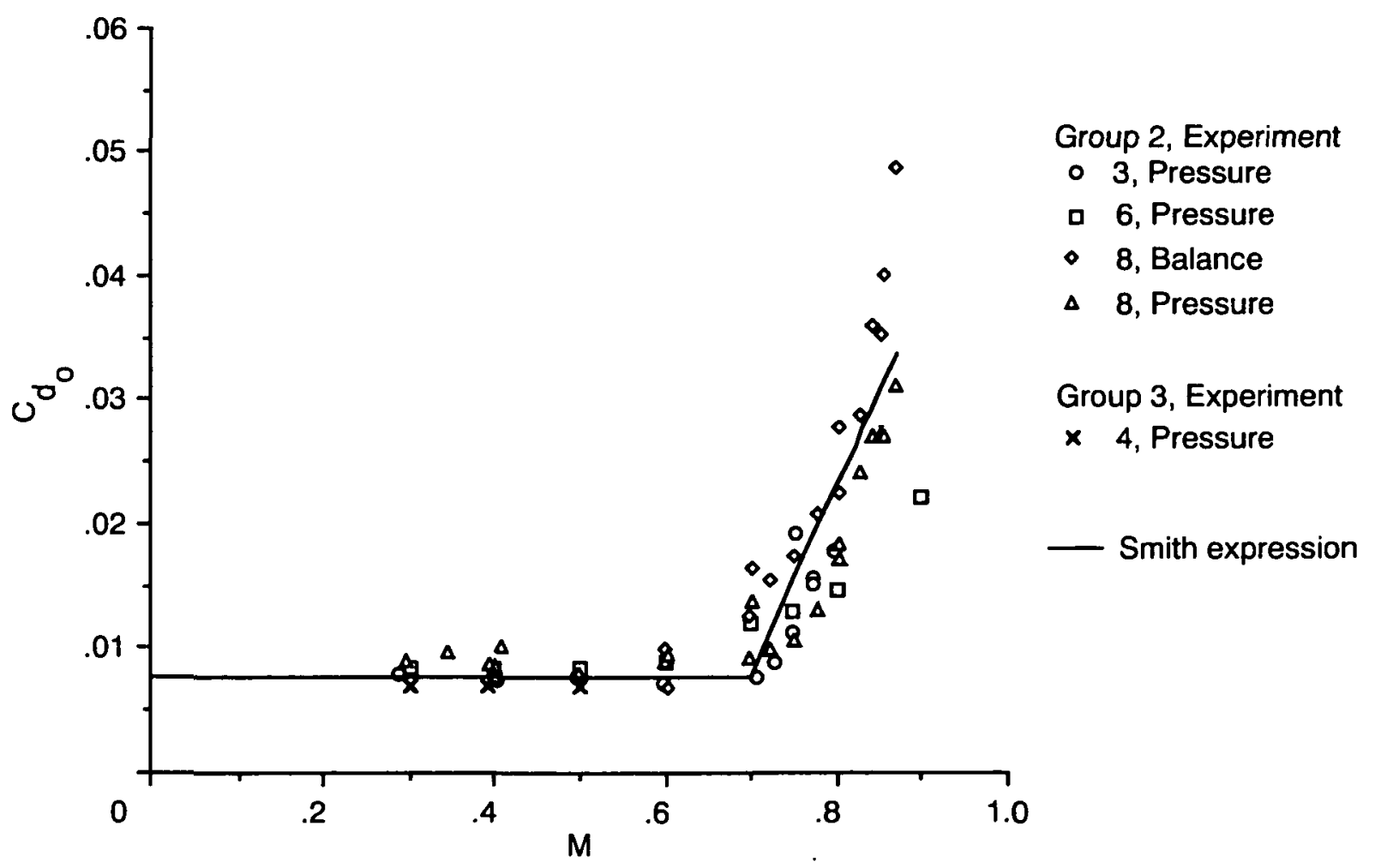

Figure 14. SC1094R8 drag coefficient at zero lift versus Mach number. 


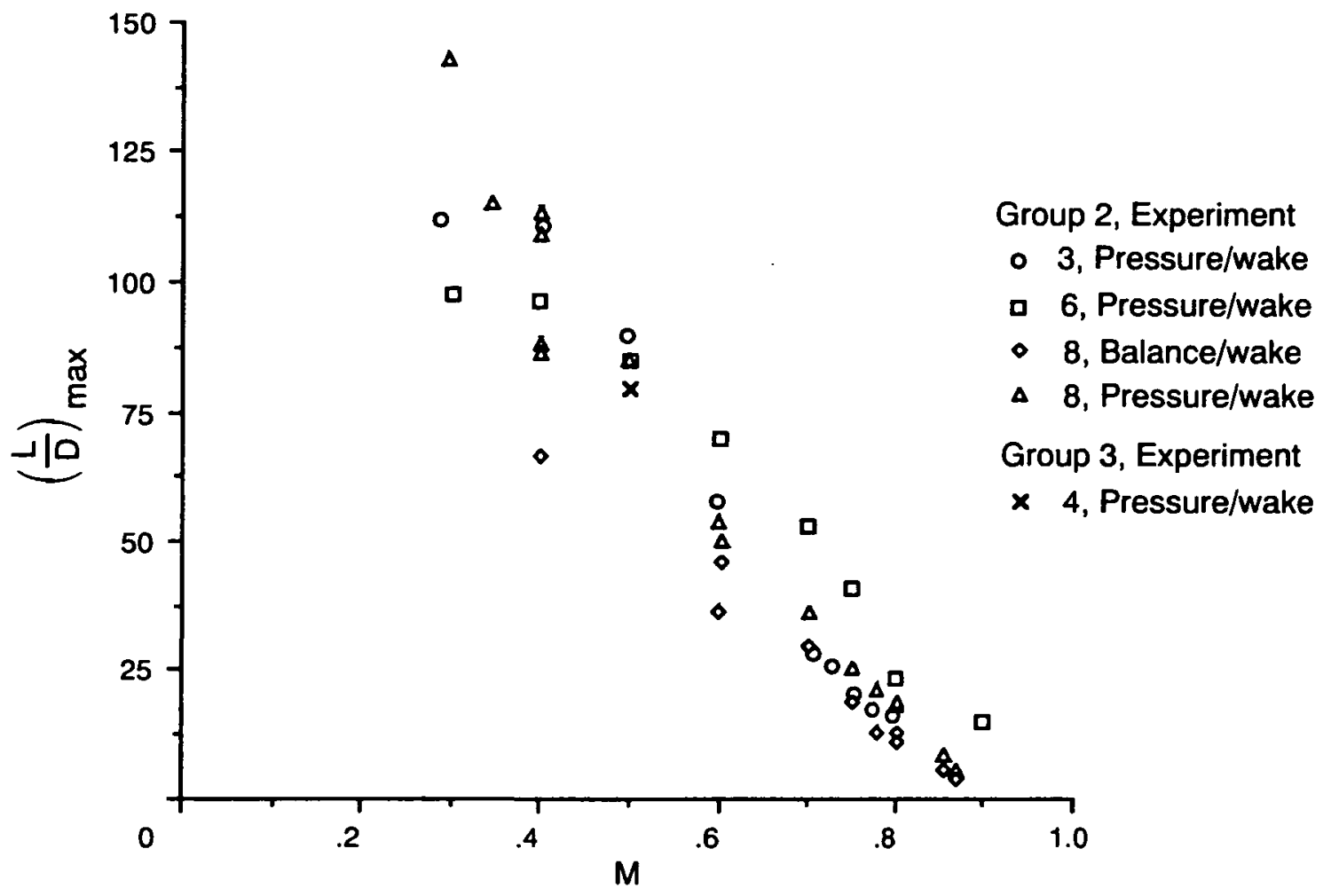

Figure 15. SC1094R8 maximum lift-to-drag ratio versus Mach number.

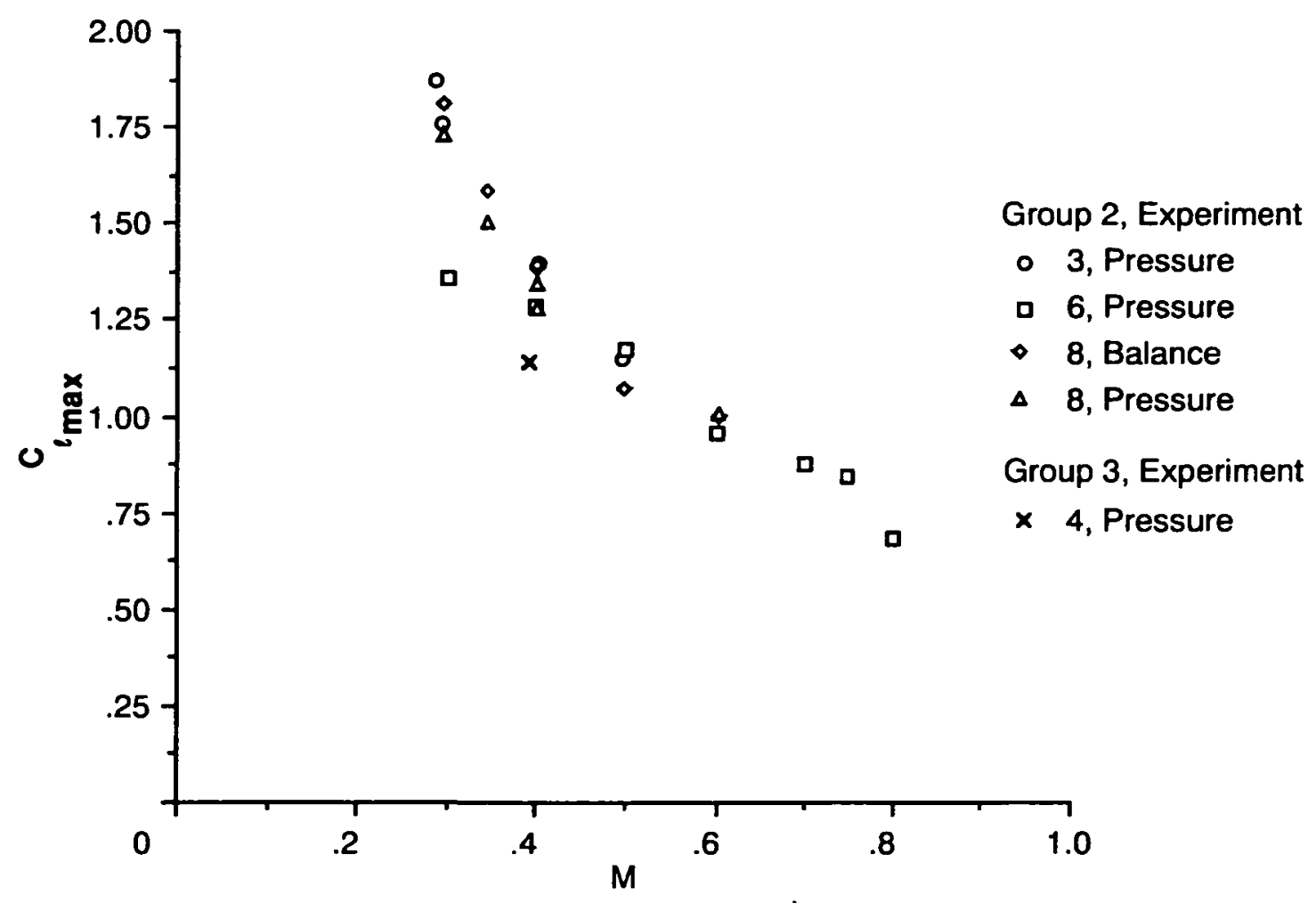

Figure 16. SC1094R8 maximum lift coefficient versus Mach number. 


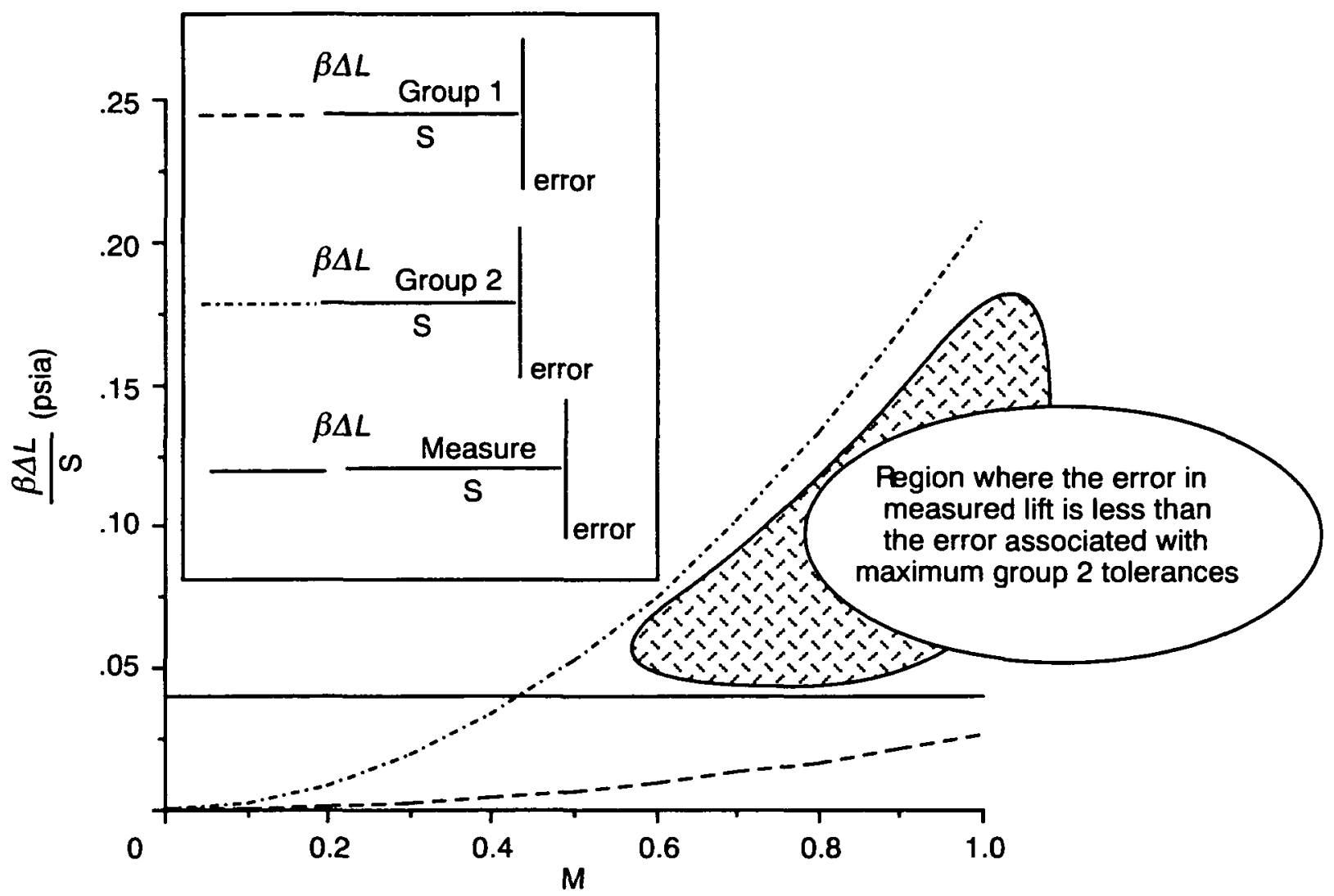

Figure 17. Comparison of the error in lift derived from measured pressure transducer steady bias error, and Group 1 and Group 2 tolerances versus Mach number for a nominal 1 degree change in angle of attack. 
Public reporting burden for this collection of information is estimated to average 1 hour per response, including the lime for reviewing instructions, searching existing data sources, gathering and maintaining the data needed, and completing and reviewing the collection of inlormation. Send comments regarding this burden estimate or any other aspect of this collection of information, including suggestions for reducing this burden, to Washington Headquarters Services, Directorate tor intormation Operations and Peports, 1215 Jefterson Davis Highway. Suite 1204, Arlington, VA 22202-4302, and to the Office of Management and Budget, Paperwork Reduction Project (0704-0188), Washington. DC 20503.

\begin{tabular}{|l|l|l}
\hline 1. AGENCY USE ONLY (Leave blenk) & $\begin{array}{c}\text { 2. REPORT DATE } \\
\text { September } 1993\end{array}$ & $\begin{array}{c}\text { 3. REPORT TYPE AND DATES COVERED } \\
\text { Technical Memorandum }\end{array}$ \\
\hline
\end{tabular}

4. TITLE ANO SUBTITLE

A Critical Assessment of UH-60 Main Rotor Blade Airfoil Data

5. FUNDING NUMBERS

6. AUTHOR(S)

$505-59-36$

Joseph Totah

8. PERFoRMING ORGANIZATION REPORT NUMBER

Ames Research Center

Moffett Field, CA 94035-1000

A-93004

9. SPONSORING/MONITORING AGENCY NAME(S) AND ADDRESS(ES)

10. SPONSORING/MONITORING AGENCY REPORT NUMBER

National Aeronautics and Space Administration

Washington, DC 20546-0001

NASA TM-103985

11. SUPPLEMENTARY NOTES

Point of Contact: Joseph Totah, Ames Research Center, MS 237-5, Moffett Field, CA 94035-1000

\section{(415) 604-5057}

Presented at 11th Annual Applied Aerodynamics Meeting, August 9-13, 1993, Monterey, California 128. DISTRIBUTION/AVAILABILITY STATEMENT

Unclassified - Unlimited

Subject Category 02

13. ABSTRACT (Maximum 200 words)

Many current comprehensive rotorcraft analyses employ lifting-line methods that require main rotor blade airfoil data, typically obtained from wind tunnel tests. In order to effectively evaluate these lifting-line methods, it is of the utmost importance to ensure that the airfoil section data are free of inaccuracies. A critical assessment of the SC1095 and SC1094R8 airfoil data used on the UH-60 main rotor blade was performed for that reason. Nine sources of wind tunnel data were examined, all of which contain SC1095 data and four of which also contain SC1094R8 data. Findings indicate that the most accurate data were generated in 1982 at the 11-Foot Wind Tunnel Facility at NASA Ames Research Center and in 1985 at the 6-inch-by-22-inch transonic wind tunnel facility at Ohio State University. It has not been determined if data from these two sources are sufficiently accurate for their use in comprehensive rotorcraft analytical models of the UH-60. It is recommended that new airfoil tables be created for both airfoils using the existing data. Additional wind tunnel experimentation is also recommended to provide high quality data for correlation with these new airfoil tables.

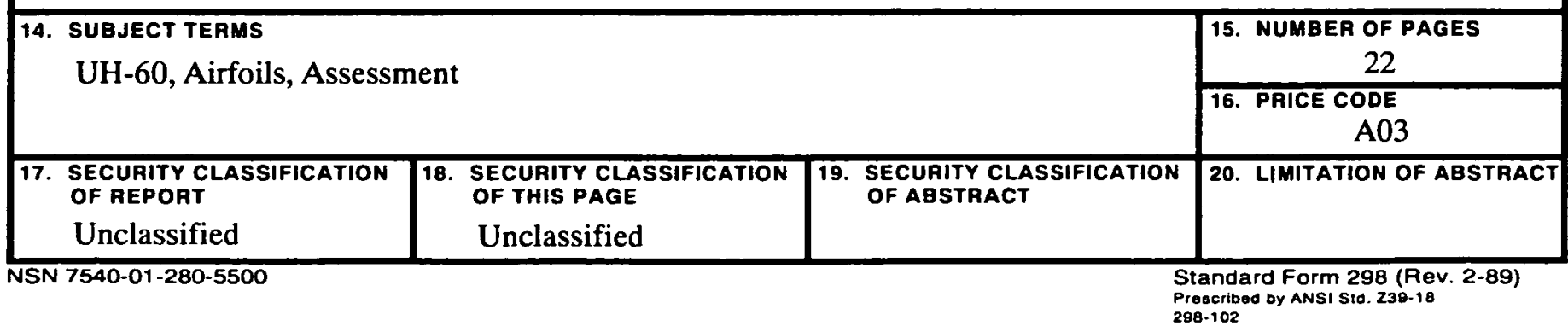

